\title{
Source identification of short-lived air pollutants in the Arctic using statistical analysis of measurement data and particle dispersion model output
}

\author{
D. Hirdman ${ }^{1}$, H. Sodemann ${ }^{1}$, S. Eckhardt ${ }^{1}$, J. F. Burkhart ${ }^{1}$, A. Jefferson ${ }^{2,3}$, T. Mefford ${ }^{2,3}$, P. K. Quinn ${ }^{4}$, S. Sharma ${ }^{5}$, \\ J. Ström ${ }^{6}$, and A. Stohl ${ }^{1}$ \\ ${ }^{1}$ Norwegian Institute for Air Research (NILU), Norway \\ ${ }^{2}$ National Oceanic \& Atmospheric Administration (NOAA) Earth System Research Laboratory (ESRL) Global Monitoring \\ Division, USA \\ ${ }^{3}$ Cooperative Institute for Research in Environmental Sciences, University of Colorado, USA \\ ${ }^{4}$ National Oceanic \& Atmospheric Administration (NOAA) Pacific Marine Environmental Lab (PMEL), USA \\ ${ }^{5}$ Environment Canada, Science and Technology Branch, Climate Research Directorate, Canada \\ ${ }^{6}$ Norwegian Polar Institute, Troms $\varnothing$, Norway
}

Received: 11 August 2009 - Published in Atmos. Chem. Phys. Discuss.: 24 September 2009

Revised: 8 January 2010 - Accepted: 13 January 2010 - Published: 25 January 2010

\begin{abstract}
As a part of the IPY project POLARCAT (Polar Study using Aircraft, Remote Sensing, Surface Measurements and Models, of Climate Chemistry, Aerosols and Transport), this paper studies the sources of equivalent black carbon (EBC), sulphate, light-scattering aerosols and ozone measured at the Arctic stations Zeppelin, Alert, Barrow and Summit during the years 2000-2007. These species are important pollutants and climate forcing agents, and sulphate and EBC are main components of Arctic haze. To determine where these substances originate, the measurement data were combined with calculations using FLEXPART, a Lagrangian particle dispersion model. The climatology of atmospheric transport from surrounding regions on a twenty-day time scale modelled by FLEXPART shows that the stations Zeppelin, Alert and Barrow are highly sensitive to surface emissions in the Arctic and to emissions in high-latitude Eurasia in winter. Emission sensitivities over southern Asia and southern North America are small throughout the year. The high-altitude station Summit is an order of magnitude less sensitive to surface emissions in the Arctic whereas emissions in the southern parts of the Northern Hemisphere continents are more influential relative to the other stations. Our results show that for EBC and sulphate measured at Zeppelin, Alert and Barrow, northern Eurasia is the dominant
\end{abstract}

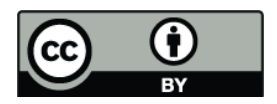

Correspondence to: D. Hirdman (dhi@nilu.no) source region. For sulphate, Eastern Europe and the metal smelting industry in Norilsk are particularly important. For $\mathrm{EBC}$, boreal forest fires also contribute in summer. No evidence for any substantial contribution to EBC from sources in southern Asia is found. European air masses are associated with low ozone concentrations in winter due to titration by nitric oxides, but are associated with high ozone concentrations in summer due to photochemical ozone formation. There is also a strong influence of ozone depletion events in the Arctic boundary layer on measured ozone concentrations in spring and summer. These results will be useful for developing emission reduction strategies for the Arctic.

\section{Introduction}

In the late 19th century, some of the early Arctic explorers noticed "dirty" deposits on the ice and snow in remote areas of the Arctic and speculated on their origin (Nordenskiöld, 1883; Nansen, 1961; Garrett and Verzella, 2008). Around the year of 1894, Nansen hypothesized that these deposits must have been transported via the atmosphere from faraway source regions but he did not relate them to air pollution. While it cannot be proven that these old reports of "dirty snow" were indeed caused by air pollution, this is a likely explanation. A historical ice-core record of black carbon (BC) shows that $\mathrm{BC}$ concentrations over Greenland peaked around

Published by Copernicus Publications on behalf of the European Geosciences Union. 
1910 (McConnell et al., 2007). Even though BC concentrations now are likely much lower than in the beginning of the 20th century current pollution events can indeed cause a visible discoloration of the snow (Stohl et al., 2007) and similar discolorations might have been observed already by Nordenskiöld (1883) and Nansen (1961) in the late 1800s. The anecdotal evidence for air pollution in the Arctic was forgotten and the Arctic was long considered a pristine place, until pilots flying over the North American Arctic in the 1950s observed widespread haze (Greenaway, 1950; Mitchell, 1957) that could be seen every winter and early spring. It took until the 1970s for scientists to realize that the haze was air pollution transported from the middle latitudes (Rahn et al., 1977; Rahn and McCaffrey, 1980; Iversen and Joranger, 1985; Barrie, 1986).

Arctic haze is a condition of reduced visibility. When viewed away from the sun it appears greyish-blue, looking into the sun it appears reddish-brown. It typically has a layered structure but on average no distinct upper and lower boundaries, and produces none of the optical phenomena that would be expected if it were composed of ice crystals (Barrie, 1986). The haze is generally composed of sulphate and particulate organic matter and to a lesser extent ammonium, BC, nitrate, dust aerosols and distinct heavy metals (Quinn et al., 2007), and it is accompanied by enhanced concentrations of gaseous pollutants (Barrie, 1986). One of the striking things about Arctic haze is its strong seasonal variation. Both the optical effects of the haze and the concentrations of its major constituents have a pronounced winter-spring maximum and summer minimum. Rahn (1982), for instance has shown that the intensity of the haze, as expressed by its optical depth, or turbidity, is several times greater in spring than in summer.

Recently, there has been renewed interest in Arctic air pollution because of its potential effects on climate. Warming is proceeding fastest in the Arctic due to strong feedbacks at high latitudes. While long-lived greenhouse gases undoubtedly are the strongest drivers of climate change, Quinn et al. (2008) argue that short-lived pollutants may also contribute to the Arctic warming and ice melt. The melt of snow/ice triggers further feedback mechanisms through a decrease of the albedo (Flanner and Zender, 2006; Flanner et al., 2007). BC changes the radiative balance in the Arctic through absorption of shortwave radiation in the atmosphere as well as by decreasing the surface albedo when deposited on snow or ice (Warren and Wiscombe, 1985; Hansen and Nazarenko, 2004). Tropospheric ozone $\left(\mathrm{O}_{3}\right)$ affects the Arctic atmosphere both locally by altering the radiation fluxes as well as more remotely by modulating heat transport into the Arctic (Shindell, 2007). Sulphate and nitrate aerosols cause scattering of shortwave radiation and also modify the optical properties of clouds (indirect aerosol effects). While this generally leads to a cooling of the surface, aerosols may also lead to increased thermal emissivity of thin Arctic clouds and, thus, a warming of the surface (Garrett and Zhao, 2006). Reductions in the concentration levels of short-lived pollu- tants could be an effective means to slow climate change in the Arctic (Quinn et al., 2008). However, in order to develop appropriate emission reduction strategies, the source regions of Arctic air pollution must be known quantitatively.

Surfaces of constant potential temperature form folded shells over the Arctic with minimum values in the boundary layer (Klonecki et al., 2003; Stohl, 2006). If transport occurs along isentropes, the potential temperature in pollution source regions must be the same as in the layers where Arctic Haze is found (Raatz and Shaw, 1984; Iversen and Joranger, 1985). This isentropic transport emphasizes relatively cold geographical regions such as Northern Eurasia (in winter) in contrast to regions further south that are too warm for air masses to reach the Arctic lower troposphere on a direct transport route (Rahn, 1981; Barrie, 1986).

Current emissions in the high Arctic (north of $70^{\circ} \mathrm{N}$ ) are negligible. However, Gautier et al. (2009) suggests that $30 \%$ of the world's undiscovered gas and $13 \%$ of undiscovered oil may be found in the Arctic. If these resources are exploited, emissions in the Arctic could increase strongly and this would probably have a dramatic impact on Arctic pollutant concentrations near the surface. Furthermore, with retreating Arctic sea ice in summer, commercial shipping in the Arctic may become feasible. Several studies suggest a large potential influence of these emissions on $\mathrm{O}_{3}$ and $\mathrm{BC}$ concentrations in the Arctic (Granier et al., 2006; Dalsøren et al., 2007; Lack et al., 2008).

Climate models and atmospheric chemistry transport models generally have problems reproducing the high observed Arctic haze aerosol concentrations (Hoyle et al., 2007). While there is some consensus on the major source regions of Arctic air pollutants, there are also considerable differences in the relative importance of different source regions between the various models (Shindell et al., 2008) and discussions about the role of distant source regions like Southern Asia (Koch and Hansen, 2005; Stohl, 2006). In a situation where models are not fully conclusive, studies based on observations are very important. Calculated air mass trajectories have long been the tool of choice for identifying the source regions of observed pollutants, both in case studies of extreme events (Solberg et al., 1996) as well as for statistical analyses of large data sets (Polissar et al., 1999, 2001; Eneroth et al., 2003; Sharma et al., 2004, 2006). However, the accuracy of individual trajectories is limited, especially when long transport distances are involved and when measurements are taken in the turbulent boundary layer (Stohl, 1998).

For this study, a Lagrangian particle dispersion model (LPDM) was employed for a statistical analysis of the source regions of various observed pollutants. LPDM calculations are more accurate than trajectory calculations which ignore atmospheric turbulence and convection (Stohl et al., 2002; Han et al., 2005). The major advantage is however that LPDM calculations are also more quantitative because the model output can be combined with emission fluxes from 
appropriate inventories to derive modelled source contributions which can be compared with measured data of longlived species, thus allowing validation of the simulated transport (Stohl et al., 2006, 2007).

This paper is structured as follows: in Sect. 2, the methods used will be described. Subsequently, in Sect. 3.1, the climatology of atmospheric transport towards the four Arctic observatories, Zeppelin (Spitsbergen, Norway), Alert (Canada), Barrow (Alaska) and Summit (Greenland) will be presented. In Sect. 3.2, the potential source regions of several observed parameters (equivalent $\mathrm{BC}$ (EBC), sulphate, light scattering aerosols and $\mathrm{O}_{3}$ ) will be investigated for the years 20002007. Finally, conclusions will be drawn.

\section{Methods}

\subsection{Measurement sites}

The measurement data used in this study comes from four sites located in different parts of the Arctic (Fig. 1): Zeppelin, Spitsbergen, Norway $\left(11.9^{\circ} \mathrm{E}, 78.9^{\circ} \mathrm{N}, 478 \mathrm{~m}\right.$ a.s.l.), Alert, Canada $\left(62.3^{\circ} \mathrm{W}, 82.5^{\circ} \mathrm{N}, 210 \mathrm{~m}\right.$ a.s.1.), Barrow, Alaska $\left(156.6^{\circ} \mathrm{W}, 71.3^{\circ} \mathrm{N}, 11 \mathrm{~m}\right.$ a.s.l.) and Summit, Greenland $\left(38.4^{\circ} \mathrm{W}, 72.6^{\circ} \mathrm{N}, 3208 \mathrm{~m}\right.$ a.s.1.). Zeppelin station is situated on a mountain ridge on the western coast of Spitsbergen. Due to the usually stable stratification of the atmosphere contamination from the small nearby community of Ny Ålesund located at the coast is minimal. Air masses can arrive either from the ice-free North Atlantic Ocean or from the generally ice-covered Arctic Ocean. Alert station is located the furthest north of all the Arctic stations on the northeastern tip of Ellesmere Island (Helmig et al., 2007a). The surroundings, both land and ocean, are mainly ice or snow covered during 10 months of the year. Barrow station lies $8 \mathrm{~km}$ northeast from a small settlement on a small land tip, and it is surrounded by the Arctic Ocean on all sides except south where there is Arctic tundra (Helmig et al., 2007a, b). Hence, Barrow station is influenced by both maritime as well as continental air. Summit station is located on the top of the Greenland glacial ice sheet, and surrounded by very flat and homogeneous terrain for more than $100 \mathrm{~km}$ in all directions (Helmig et al., 2007a).

\subsection{Measurement data}

Measured concentrations of EBC (derived from the aerosol light absorption coefficient), sulphate, the aerosol light scattering coefficient and $\mathrm{O}_{3}$ are used in this study. Sulphate and $\mathrm{BC}$ are important components of Arctic haze, with sulphate being responsible mainly for the light-scattering effects and $\mathrm{BC}$ primarily responsible for the light absorption effects of Arctic haze aerosol (Polissar et al., 1999). Both components can also exist in an internal aerosol mixture and can in addition influence cloud microphysical properties. $\mathrm{O}_{3}$ is a secondary pollutant and a strong greenhouse gas which contributes to warming of the Arctic (Shindell, 2007).

Table 1 summarizes the measurement data used here. The EBC, aerosol light scattering and $\mathrm{O}_{3}$ data records from all stations have a time resolution of $1 \mathrm{~h}$. Data were averaged to match the model time resolution of $3 \mathrm{~h}$ (see Sect. 2.2). For sulphate, daily samples were taken at Zeppelin, whereas the sample duration at Alert was 7 days and at Barrow it varied between 1 and 5 days depending on season. The 3-hourly model results were averaged to the corresponding sample length. Particularly for Alert and Barrow the sampling length for sulphate is often too long to resolve individual transport events, which limits the statistical analysis of source regions as will be discussed in further detail in Sect. 3.2.2.

The information on light absorbing particles is collected with particle soot absorption photometers (PSAP) at Zeppelin and Barrow and with aethalometers at Alert and Summit. PSAP measurements are reported as the particle light absorption coefficient $\sigma_{\text {ap }}$ (Bond et al., 1999), whereas aethalometer output is reported directly as BC concentrations through an internal conversion using an assumed mass absorption efficiency. Conversion between $\sigma_{\mathrm{ap}}$ and $\mathrm{BC}$ is not straightforward. It requires the assumptions that all the light absorption measured is from $\mathrm{BC}$, and that all $\mathrm{BC}$ has the same light absorption efficiency. Therefore, PSAP data are reported as EBC, where $\sigma_{\text {ap }}$ values have been converted approximately to $\mathrm{BC}$ mass concentration using a value of $10 \mathrm{~m}^{2} \mathrm{~g}^{-1}$, typical of aged BC aerosol (Bond and Bergstrom, 2006). The conversion to $B C$ in the aethalometers is done internally but relies on the same assumptions, so these data will be referred to as EBC as well.

PSAP measurements have been made at Barrow since October, 1997, as part of the standard NOAA/ESRL/GMD aerosol optical measurements system design (Delene and Ogren, 2002). The measurements at Zeppelin are performed using a custom built PSAP that is based on the same measurement principle. The responses of both the PSAPs and the aethalometer depend on the loading of particles on the filter and on the amount of light that the particles scatter (Bond et al., 1999; Weingartner et al., 2003; Arnott et al., 2005). The Barrow and Zeppelin PSAP data were corrected for these dependencies according to the procedure described by Bond et al. (1999), while no corrections were applied to the aethalometer measurements from Alert and Summit. To avoid local contamination by emissions from the town of Barrow is the Barrow PSAP data routinely screened where only values were used when the wind direction fell within the "clean-air sector" from 0-130 (Bodhaine, 1995). This screening very likely also affects how representative these data are when analyzing potential source regions, which will be discussed in Sect. 3.2.1. At Summit, the diesel generator and the camp are local pollution sources. Thus, data were used only when the air masses approach from the "cleanair sector" $\left(111-248^{\circ}\right)$ in agreement with an earlier study by Kahl et al. (1997). 
Table 1. Measurement data used in this study. Further information on the instrumentation and data can be found in the listed references.

\begin{tabular}{llcccl}
\hline Station & Species & Time period & Time resolution & Data availability & References \\
\hline Zeppelin & EBC & $2002-2007$ & $1 \mathrm{~h}$ & $84.0 \%$ & Krecl et al. (2007) \\
Zeppelin & Ozone & $2000-2007$ & $1 \mathrm{~h}$ & $96.1 \%$ & Aas et al. (2008) \\
Zeppelin & NSS sulphate & $2000-2006$ & $24 \mathrm{~h}$ & $97.1 \%$ & Aas et al. (2008) \\
Alert & EBC & $2000-2006$ & $1 \mathrm{~h}$ & $84.3 \%$ & Sharma et al. (2004, 2006) \\
Alert & Ozone & $2000-2007$ & $1 \mathrm{~h}$ & 82.8 & Worthy et al. (2003) \\
Alert & NSS sulphate & $2000-2006$ & 7 days & $100 \%$ & Sirois and Barrie (1999) \\
Barrow & EBC & $2000-2007$ & $1 \mathrm{~h}$ & $50.9 \%$ & Sharma et al. (2006) \\
Barrow & Ozone & $2000-2006$ & $1 \mathrm{~h}$ & $94.7 \%$ & Helmig et al. (2007a) \\
Barrow & NSS sulphate & $2000-2006$ & $1-5$ days & $70.2 \%$ & Sirois and Barrie (1999) \\
Barrow & Light scattering aerosols & $2000-2007$ & $1 \mathrm{~h}$ & $53.0 \%$ & Sheridan et al. (2001) \\
Summit & EBC & $2003-2006$ & $1 \mathrm{~h}$ & $41.9 \%$ & Sharma et al. (2009) \\
Summit & Ozone & $2000-2007$ & $1 \mathrm{~h}$ & $77.4 \%$ & Helmig et al. (2007a) \\
\hline
\end{tabular}

Sulphate and other inorganic ions were measured at Zeppelin, Alert and Barrow by ion chromatography analysis on filter samples taken at daily or longer intervals (Table 1). Measured sulphate concentrations were corrected for the influence from sea-salt by using measurements of sodium on the same filters and a ratio of sulphate to sodium in seawater. The stations sample different particle size ranges when measuring sulphate. At Zeppelin, particles smaller than about $10 \mu \mathrm{m}$ are collected, at Alert, the total suspended particulates (TSP) are sampled, and at Barrow, sub- and super-micron particles are collected separately but in this study only the submicron measurements are used.

The light scattering coefficient is measured at Barrow using two independent nephelometer-based systems (Sheridan et al., 2001). The data are subject to the same filtering as the light absorption data, which means that only data from the "clean sector" are used here.

Surface ozone concentrations are measured using UV absorption instruments based on the absorption of UV radiation at $253.7 \mathrm{~nm}$, all in agreement with the principle guidelines from the International Organization for Standardization (ISO) (ISO 13964:1998).

The time period considered in this study (2000-2007) was chosen such that a relatively uniform set of recent measurement data from the four Arctic stations was available. Some data sets do not extend much further back in time. The time period is also a compromise between having available a large enough data set for obtaining robust statistical results and to avoid using a too long time period, over which emission changes in the major source regions could be substantial. The time period is representative in respect to atmospheric transport over the last two decades which will be presented in a follow-up paper where also the effects of emission changes over decadal periods are studied.

\subsection{Model calculations}

To date, trajectory models have been the most broadly used tools for the statistical analysis of the atmospheric transport of trace substances to measurement sites. We make use of the widely applied Lagrangian particle dispersion model (LPDM) FLEXPART (Stohl et al., 1998, 2005; Forster et al., 2007). FLEXPART calculates the trajectories of socalled tracer particles using the mean winds interpolated from the analysis fields plus parameterizations representing turbulence and convective transport. These processes, which are not included in standard trajectory models, are important for a realistic simulation of the transport of trace substances (Stohl et al., 2002). Including them makes the calculations more computationally demanding and the statistical analysis of the model results becomes more complex. However, Han et al. (2005) concluded that the reactive gaseous mercury (RGM) sources could be identified more precisely with LPDM calculations than with the trajectory model calculations.

FLEXPART was run backward in time using operational analyses from the European Centre for Medium-Range Weather Forecasts (ECMWF, 2002) with $1^{\circ} \times 1^{\circ}$ resolution for the period 2002-2007. For earlier years the ERA-40 re-analysis data were used (Uppala et al., 2005) also with $1^{\circ} \times 1^{\circ}$ resolution. Analyses at 00:00, 06:00, 12:00 and 18:00 UTC and 3-h forecasts at 03:00, 09:00, 15:00 and 21:00 UTC were used. During every 3-h interval, 40000 particles were released at the measurement point and followed backward for 20 days. The choice of 20 days is somewhat subjective, but it is comparable to the atmospheric lifetimes of most of the species studied in this paper and therefore should be long enough to capture transport from the most relevant source regions.

In backward mode, FLEXPART calculates an emission sensitivity function $S$, called source-receptor-relationship by 
Seibert and Frank (2004). The $S$ value (in units of $\mathrm{s} \mathrm{m}^{-3}$ ) in a particular grid cell is proportional to the particle residence time in that cell and measures the simulated concentration at the receptor that a source of unit strength $\left(1 \mathrm{~kg} \mathrm{~s}^{-1}\right)$ in the cell would produce for an inert tracer which is not affected by chemical or other removal processes. The emission sensitivity $S$ close to the surface is of particular interest, as most emissions occur near the ground. Thus, $S$ values are calculated for a so-called footprint layer $0-100 \mathrm{~m}$ above ground. $S$ can be folded with emission distributions of any species to calculate receptor concentrations of that species under the assumption that the substance is inert. However, here concentrations are not calculated but instead $S$ is used directly.

\subsection{Statistical analyses}

The statistical method for analysing the measurement data and the model results is basically the same as the trajectory residence time analysis of Ashbaugh (1983) and Ashbaugh et al. (1985) but takes advantage of the superiority of the FLEXPART $S$ fields compared to simple trajectories as described in Hirdman et al. (2009). It explores where high and, respectively, low concentrations of the targeted pollutants are coming from and, thereby, infer their potential source regions. $M$ model calculations were matched with $M$ corresponding measured concentrations. From the gridded footprint emission sensitivity field $S(i, j, m)$, where $i$ and $j$ are the indices of the model output grid and $m=1, \ldots M$ are the observation numbers, the average footprint emission sensitivity $S_{\mathrm{T}}$ is calculated as

$S_{\mathrm{T}}(i, j)=\frac{1}{M} \sum_{m=1}^{M} S(i, j, m)$

$S_{\mathrm{T}}$ can also be interpreted as a flow climatology that shows the regions where air masses arriving at a station are likely to have been within the boundary layer during the 20 days prior to arrival. Next, we select the $L=M / 10$ highest (or, alternatively, the lowest) $10 \%$ of the measured concentrations and calculate the average footprint emission sensitivity

$S_{P}(i, j)=\frac{1}{L} \sum_{l=1}^{L} S(i, j, l)$

only for this data subset, where the percentile $P$ is either 10 or 90 . Both $S_{P}$ and $S_{\mathrm{T}}$ peak near the observatory as emission sensitivities generally decrease with distance from the station. This bias is removed by calculating the relative fraction $R_{P}$, where

$R_{P}=\frac{L}{M} \frac{S_{P}}{S_{\mathrm{T}}}$

and with $P$ still being either 10 or 90 , this may then be used for identifying grid cells that are likely sources (or sinks) for the parameter of interest. If the measured species were completely unrelated to air mass transport patterns then the data subset and the full data set would look the same and $R_{P}(i, j)=0.1$ would be expected for all $i, j$. The deviation from this expected value contains information on sources and sinks. When using the top decile of the measurement data, $R_{90}(i, j)>0.1$ indicates that high measured concentrations are preferentially associated with transport through grid cell $(i, j)$, making $(i, j)$ a potential source. Conversely, $R_{90}(i, j)<0.1$ indicates that cell $(i, j)$ is less likely to be a source. On the contrary, when applying this to the lowest decile of the measurement data, $R_{10}(i, j)>0.1$ indicates a likely sink in grid cell $(i, j)$, and $R_{10}(i, j)<0.1$ a source or at least the absence of a sink.

Not all features of the $R_{P}$ field are statistically significant. Particularly where $S_{\mathrm{T}}$ values are low (indicating rare transport towards the receptor even for the full data set), spurious $R_{P}$ values may occur. To remove spurious values $R_{P}(i, j)$ is only calculated in grid cells where $S_{\mathrm{T}}(i, j)>1 \times 10^{-9} \mathrm{~s} \mathrm{~m}^{-3}$. This threshold is a compromise between the need to remove spurious values and the desired large spatial coverage. To verify the statistical significance of the remaining $R_{P}$ patterns, a bootstrap resampling analysis was performed (Devore and Farnum, 1999) analogous to that used by Vasconcelos et al. (1996a) for trajectory statistics. This technique does not assume any specific distribution of the data. For every bootstrap resampling, one $S$ field is removed and a new $R_{P}$ map is created. This leads to $M+1 R_{P}$ maps from which a mean distribution for each grid cell can be derived. Only $R_{P}$ values that are statistically significant at the $90 \%$ significance level are retained. If a $R_{P}$ value falls outside of this confidence interval, a 9-point smoothing operator is employed that disperses information from neighbouring grid cells. After the smoothing, the bootstrapping is repeated and, if necessary, further smoothing is applied. These steps are repeated until all $R_{P}$ values pass the significance test. While the remaining features are all statistically significant, the interpretation must nevertheless be done carefully as there may still be systematic effects that cannot be accounted for by the bootstrapping. In a study based on back trajectories, Vasconcelos et al. (1996b) noticed that the angular resolution of the statistical analysis is better than its radial resolution. For example, transport from a clean region may be shielded from identification if a closer pollution source lies into the same direction as viewed from the station. Overall, however, the method is well suited for identifying the origin of clean and polluted air masses, respectively, arriving at the measurement stations (Hirdman et al., 2009).

The time period which is considered in the study (20002007) has been chosen in order to present our analysis on a complete and uniform set of recent measurement data from these Arctic stations as possible, where some data sets do not extend much further back in time. In the compromise between obtaining robust statistical results and the necessity of a cut off at some point to avoid including changes in emissions from the major source regions, the specific time period was considered to be adequate. It is beyond the scoop of this 

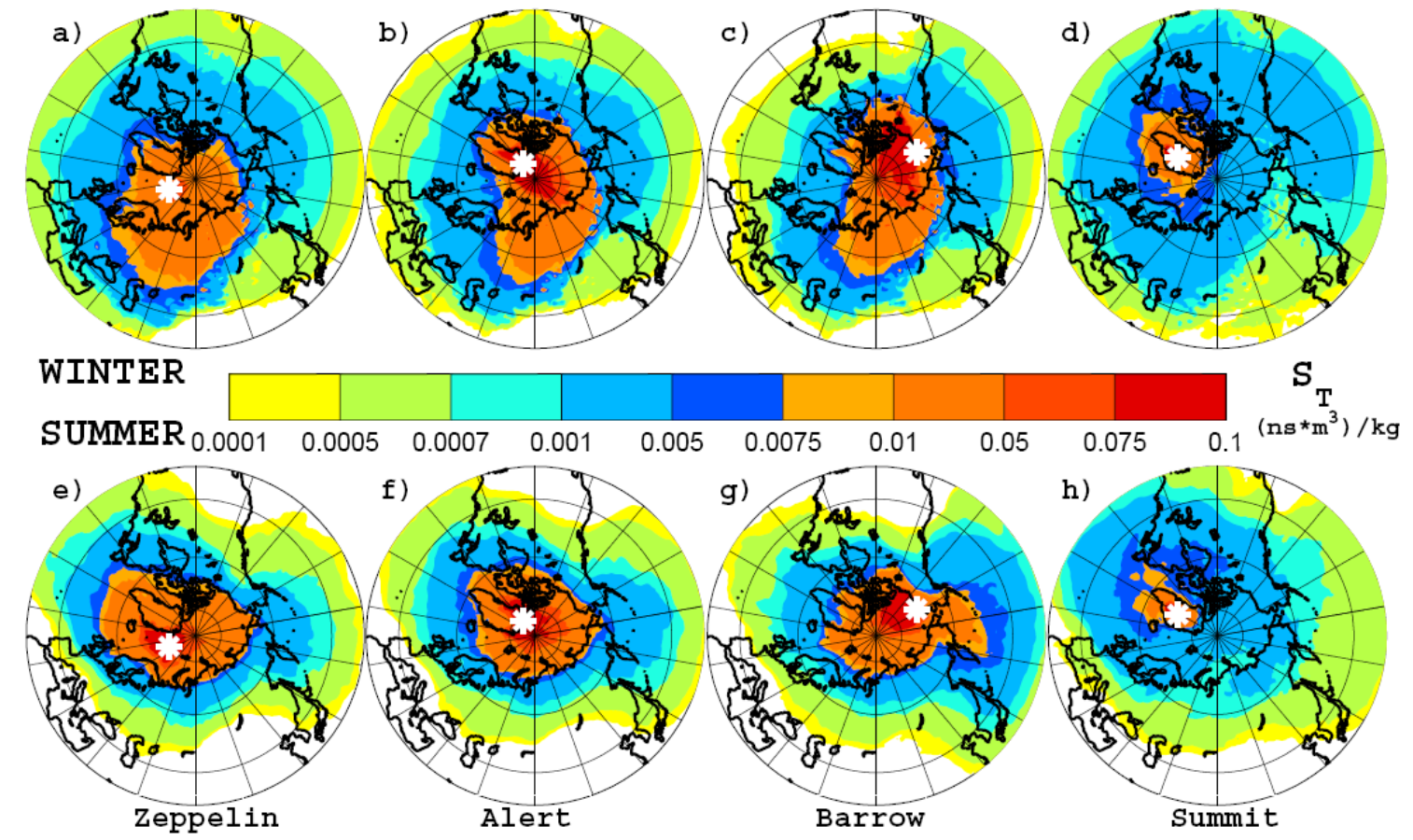

Fig. 1. Transport climatologies $\left(S_{\mathrm{T}}\right)$, for winter (top row) and summer (bottom row) and for the Arctic stations: Barrow, Alert, Zeppelin and Summit for the years 2000-2007. The stations locations are marked with a white asterisk.

paper to address changes in the emission strengths but this will be investigated in a follow-up paper.

\section{Results}

\subsection{Transport climatologies}

General transport climatologies are compared by plotting the total footprint sensitivity $S_{\mathrm{T}}$ for the different measurement stations (Fig. 1). $S_{\mathrm{T}}$ shows the overall sensitivity to surface emissions during the last 20 days of transport and, thus, indicates where surface sources can potentially influence the measurements. Plots of $S_{\mathrm{T}}$ can also be interpreted as flowclimatologies where high values indicate frequent transport reaching the station.

High $S_{\mathrm{T}}$ values for all low-altitude surface stations are primarily limited to the Arctic (Fig. 1, here in orange/red). Thus, emissions within the Arctic can strongly influence pollutant concentrations at all stations, while emissions of the same strength outside the Arctic would have a much smaller impact. However, there is a strong seasonal variation. In winter (DJF), relatively high $S_{\mathrm{T}}$ values extend towards northern Eurasia. This is consistent with our understanding of atmospheric transport patterns in the Arctic, with winter-time lowlevel transport into the Arctic occurring primarily from Eurasia (Rahn and McCaffrey, 1980; Carlson, 1981; Barrie, 1986; Klonecki et al., 2003; Stohl, 2006; Quinn et al., 2007; Law and Stohl, 2007; Shindell et al., 2008). In summer (JJA), high $S_{\mathrm{T}}$ values are confined to the Arctic Ocean basin and sharply decrease near the continental coasts, indicating that air masses from the relatively warmer land masses are less likely to reach the Arctic stations on a 20-day timescale. As a result, sources near the continental coasts potentially have a much larger influence on the Arctic than sources located in the continental interior. Pollution sources within the Arctic itself, which are currently quite limited, would have by far strongest influence on Arctic pollutant concentrations. For instance, increased commercial shipping with the retreat of the sea ice in summer could lead to strongly elevated concentrations of $\mathrm{BC}, \mathrm{O}_{3}$ and other pollutants in the Arctic (Granier et al., 2006; Dalsøren et al., 2007; Lack et al., 2008).

Alert (Fig. 1b, f) is the station most isolated from continental source regions due to its location deep within the Arctic. Compared to Alert, Barrow (Fig. 1c, g) samples more air masses from the North American sector of the Arctic and Zeppelin (Fig. 1a, e) samples more air from the European sector of the Arctic. All three stations are sensitive also to emissions from northern Siberia.

Transport to the Summit station (Fig. 1d, h) is distinctly different. Because of Summit's high altitude, the air has surface contact mostly over Greenland itself, whereas $S_{\mathrm{T}}$ elsewhere is low. Thus, measurements at Summit are representative for the Arctic free troposphere. Summit is also special since the remaining continental influence is mostly located over North America and Europe, whereas Siberia has relatively little influence. When considering also emission 


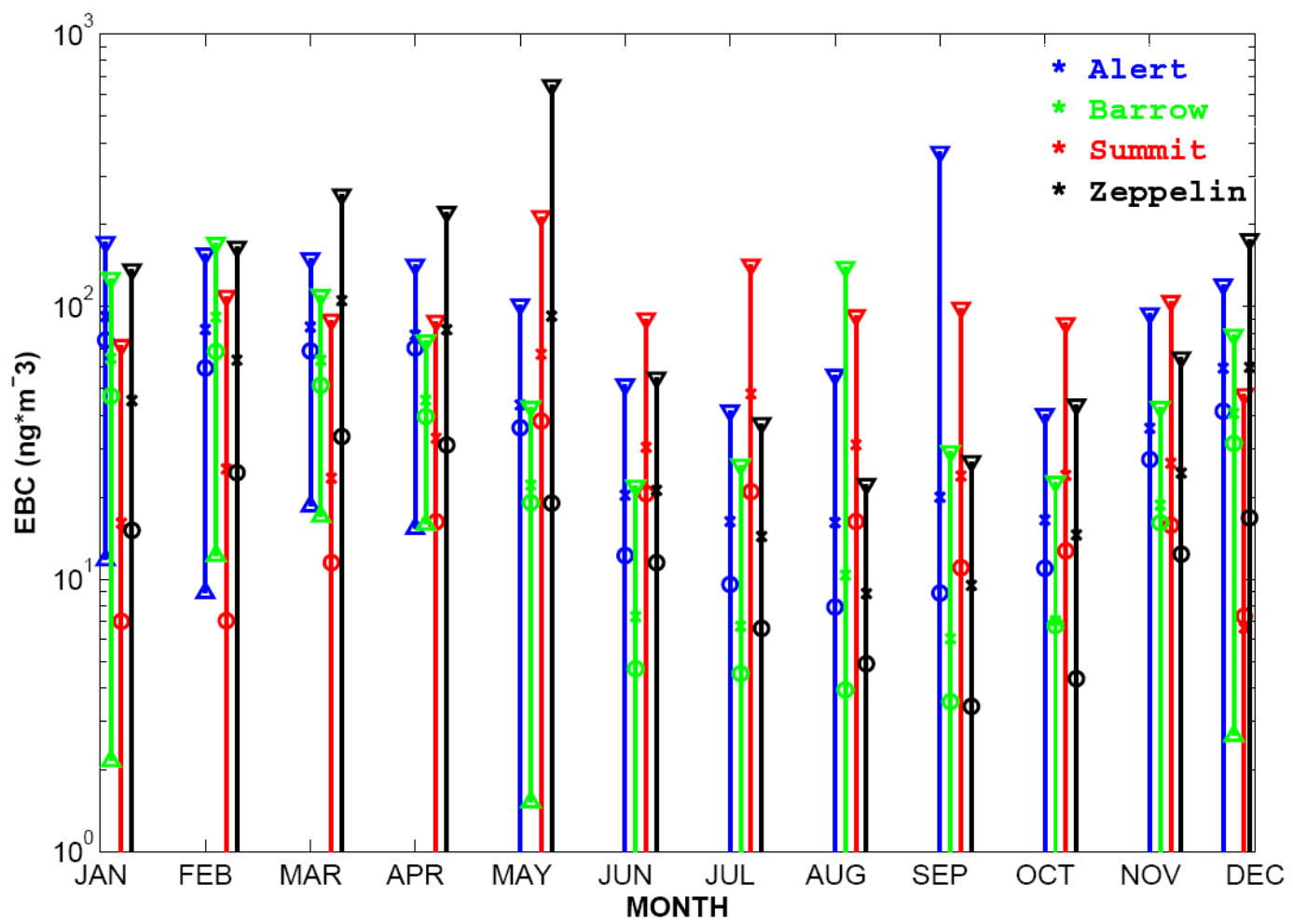

Fig. 2. Monthly averaged concentrations of measured EBC at Alert (blue), Barrow (green), Summit (red) and Zeppelin (black) during the years 2000-2007 (2000-2006 for Alert, 2003-2006 for Summit and 2002-2007 for Zeppelin). The EBC is plotted on a logarithmic scale. The mean concentration is marked with a cross, the median with a circle and bars indicate \pm 1 standard deviation. Notice that symbols for Barrow, Summit and Zeppelin are slightly offset in time for clarity of presentation.

sensitivities above the footprint layer (lowest $100 \mathrm{~m}$ ), Summit is influenced quite strongly by transport from North America (not shown) in agreement with the isobaric trajectory study by Kahl et al. (1997). This implies that sources that can emit above the boundary layer (e.g., boreal forest fires) could affect the pollution levels at Summit more strongly than at the low-altitude surface sites. It is also important to notice that while $S_{\mathrm{T}}$ values in high-latitude regions are much lower than for the other stations, the $S_{\mathrm{T}}$ values at lower latitudes are higher. For instance, $S_{\mathrm{T}}$ values in northern Siberia are an order of magnitude lower for Summit than for Alert. In, contrast, over the southern United States and southern China $S_{\mathrm{T}}$ values for Summit are higher than for Alert. This can be understood in the framework of the polar dome concept (Carlson, 1981; Stohl, 2006), where air masses from warm low-latitude areas rise isentropically as they are transported northwards. Summit, because of its high altitude, is more likely to sample these air masses than the other Arctic stations. This implies that aerosol reconstructions from inland Greenland ice cores (McConnell et al., 2007) must be interpreted cautiously because these ice cores will not be representative for the Arctic boundary layer but rather for the Arctic free troposphere and more southerly latitudes.

\subsection{Source regions}

A natural step after looking at the general atmospheric transport reaching the Arctic stations during different seasons of the year is to couple these transport calculations to the variety of species measured at these sites.

\subsubsection{Equivalent black carbon}

The measured EBC concentrations experience a clear seasonal variation with a minimum during the late summer months for all low-altitude stations (Fig. 2). For these stations, transport from lower latitudes is infrequent and removal processes such as wet scavenging by precipitation are most effective in summer, explaining the much lower summer concentrations. Summit shows a smaller but opposite seasonal variation with a maximum in late spring and early summer (Fig. 2). Summit continues sampling air from lower latitudes even in summer (Fig. 1) and is less impacted by wet scavenging by drizzle below the Arctic stratus cloud deck. Thus, the different seasonal EBC variation at Summit, is a possible explanation. Annual arithmetic mean concentrations are about the same for Barrow $\left(32.0 \mathrm{ng} \mathrm{m}^{-3}\right)$ and Summit $\left(29.6 \mathrm{ng} \mathrm{m}^{-3}\right)$ while at Alert $\left(47.1 \mathrm{ng} \mathrm{m}^{-3}\right)$ and at Zeppelin $\left(45.1 \mathrm{ng} \mathrm{m}^{-3}\right)$ higher mean concentrations are 

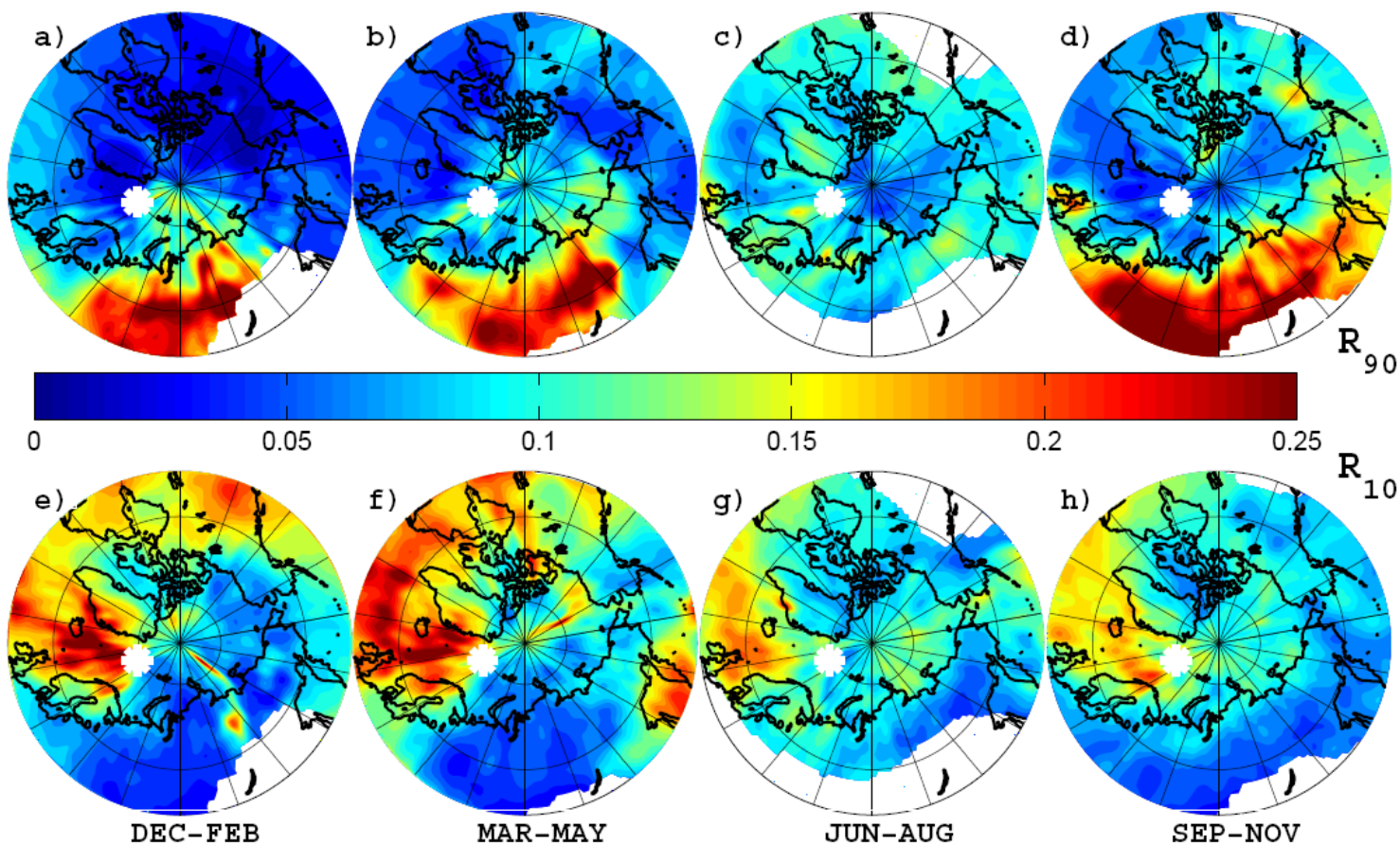

Fig. 3. Fields of $R_{90}$ (top row) and $R_{10}$ (bottom row) for measurements of EBC at the Zeppelin station during the years 2002-2007, for December-February (far left column), March-May (middle left column), June-August (middle right column) and September-November (far right column). The location of the Zeppelin station is marked by a white asterisk. White areas have been excluded from the analysis because $S_{\mathrm{T}}$ is too low.

measured. At the latter two stations, values are somewhat higher than reported in earlier studies (Sharma et al., 2006; Eleftheriadis et al., 2009). This may be due to using a different instrument at Zeppelin for this study than in Eleftheriadis et al. (2009) and a different period of investigation for Alert than in Sharma et al. (2006).

In Fig. 3 we show $R_{P}$ fields for both the highest and the lowest $10 \%$ of all EBC data measured at Zeppelin, for all for seasons. In winter, high EBC concentrations (Fig. 3a) are associated with transport especially from the central parts of Northern Eurasia where $R_{90}$ values exceed 0.2. Also at Alert and Barrow, are high $R_{90}$ values in winter completely dominated by long-range transport from Northern Eurasia (Figs. 4a and 5a), in agreement with the earlier work of Worthy et al. (1994), Polissar et al. (1999, 2001), Sharma et al. (2004, 2006) and Eleftheriadis et al. (2009). None of these stations "sees" significant influence of transport from North America or South East Asia for the top decile of EBC concentrations during winter. Episodes associated with the lowest decile of the EBC data (Figs. 3e, 4e and 5e) show transport from source free regions, or over regions where the transported air would experience strong scavenging by precipitation such as over the North Atlantic Ocean for Zeppelin and Alert or the western Pacific Ocean for Barrow.

The $R_{90}$ and $R_{10}$ patterns in spring (MAM) are generally similar to winter for Zeppelin, Alert and Barrow (Figs. 3b,f,
$4 \mathrm{~b}, \mathrm{f}$ and $5 \mathrm{~b}, \mathrm{f})$. Two exceptions are that high $R_{10}$ values are more related to transport from the North Pacific Ocean for Alert (Fig. 4f), and from the North Atlantic Ocean for Barrow.

During the summer, the picture changes completely. Notice first that $R_{90}$ values are below 0.1 almost everywhere. This indicates that surface contact is unlikely to have occurred when EBC values are high. Thus, high EBC concentrations mostly descend from the free troposphere, consistent with the higher concentrations measured at Summit during summer (see Fig. 2). For Zeppelin (Fig. 3c), the $R_{90}$ field is noisy but elevated $R_{90}$ values are noticeable over northeastern Siberia indicating the influence of frequent boreal forest fires in this region (Kasischke et al., 2005). At Alert (Fig. 4c), there is a small influence from forest fires in Alaska which is consistent with earlier conclusions of significant influences downwind from forest fires in Alaska and Canada (Forster et al., 2001; Stohl et al., 2006). For Barrow (Fig. 5c), high $R_{90}$ values occur over Alaska south of the station which can only be caused by boreal forest fires. Examining individual years, the pattern is particularly strong in 2004 (not shown) and the location of the highest $R_{90}$ values coincides very well with the location of the severe boreal forest fires in that year (Stohl et al., 2006).

In fall (SON), $R_{90}$ patterns for Zeppelin, Alert and Barrow are again similar to the winter situation, with the highest 

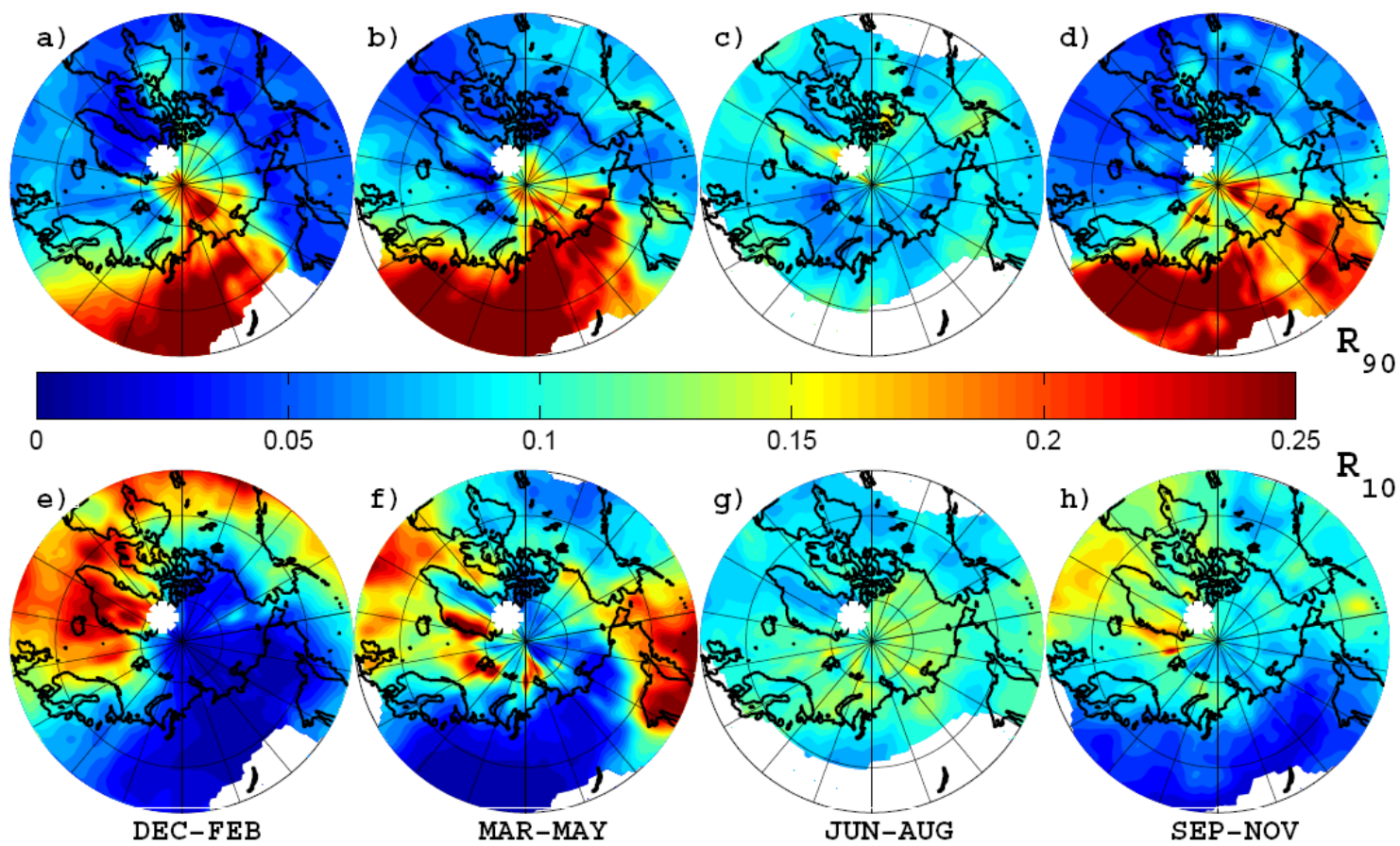

Fig. 4. Same as Fig. 3 but for the Alert station during the years 2000-2006.
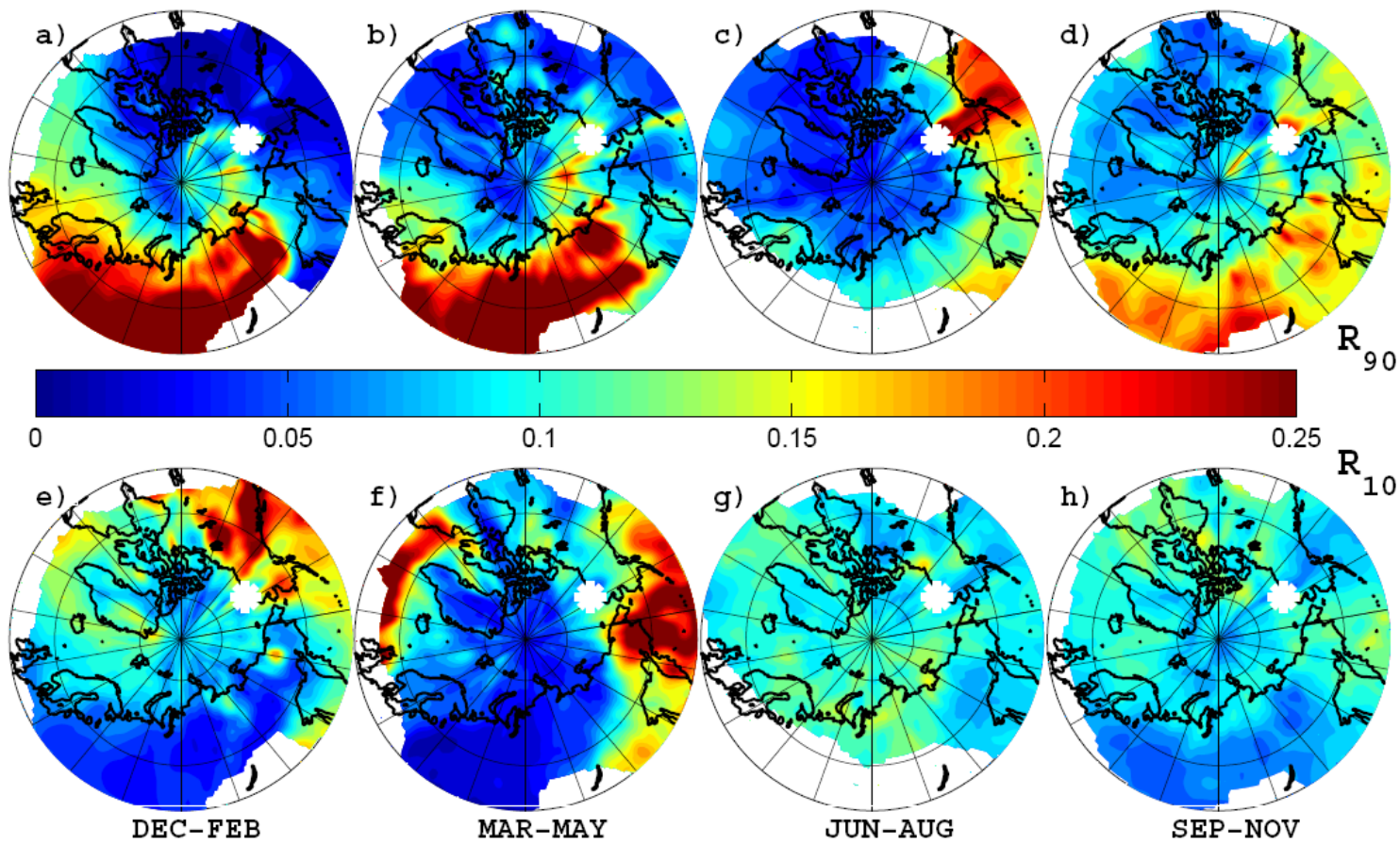

Fig. 5. Same as Fig. 3 but for the Barrow station during the years 2000-2007.

values found over Northern Eurasia (Figs. 3d, 4d, 5d). The largest difference is that $R_{90}$ values over East Asia are enhanced compared to the winter situation.
The $R_{P}$ fields for Summit differ from the other stations (Fig. 6). First of all, they are noisier because of lower $S_{\mathrm{T}}$ values, than for the other stations, and also because less data are available. In winter, larger $R_{90}$ values are associated with 

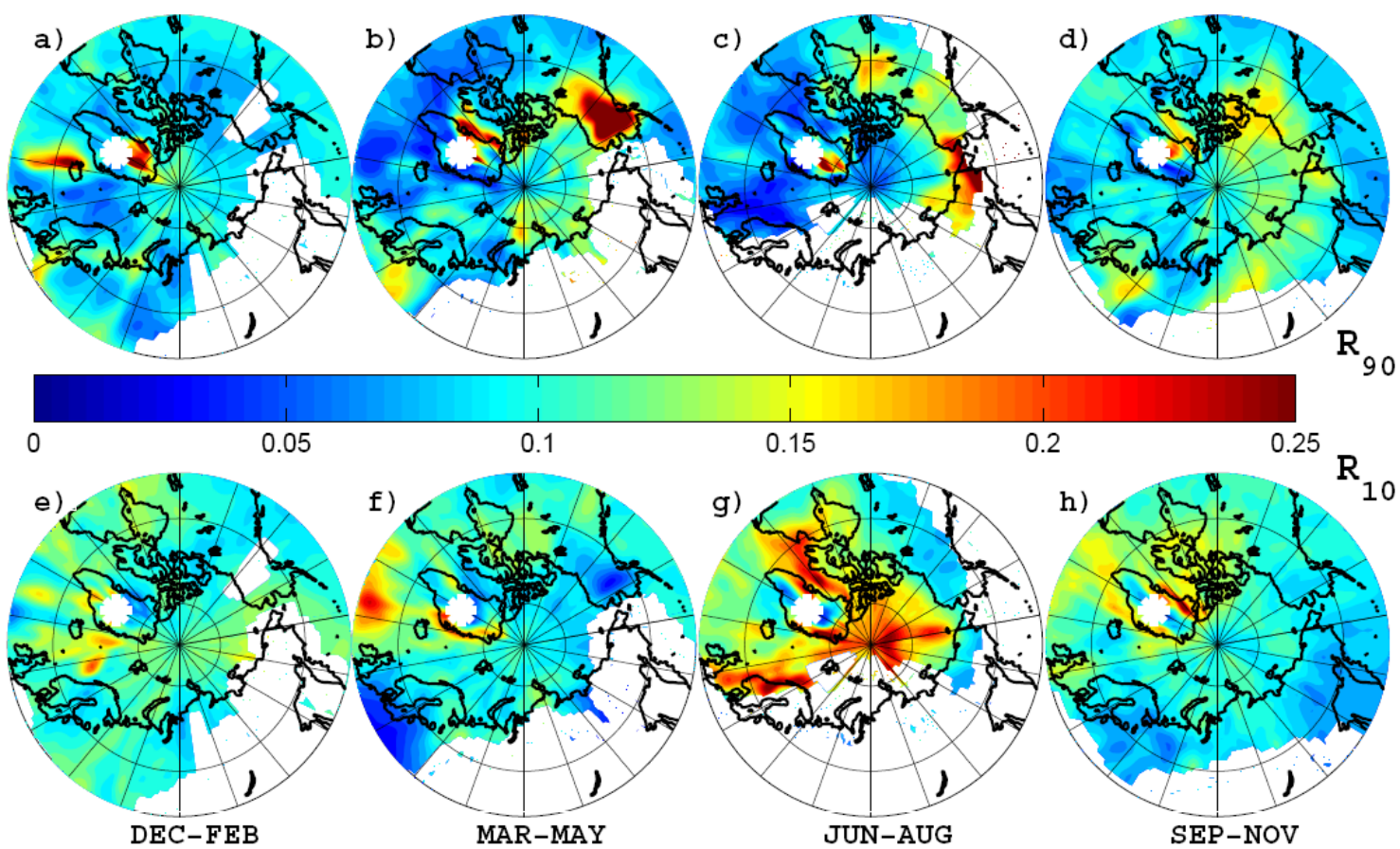

Fig. 6. Same as Fig. 3 but for the Summit station during the years 2003-2006.

transport from Iceland and to some extent also from Central Europe (Fig. 6a) while the $R_{10}$ values show increased surface contact over the Norwegian Sea and the North Atlantic Ocean (Fig. 6e). In spring, the $R_{90}$ patterns demonstrate increased sensitivity over Alaska (Fig. 6b), probably related to early forest fires and Eastern Europe as well as over the Greenland west coast where some of the larger settlements are located. Low EBC concentrations are during spring associated with transport from the North Atlantic Ocean (Fig. 6f). In summer, enhanced $R_{90}$ values are found over the continental regions on both sides of Bering Strait as well as over the north central parts of Canada (Fig. 6c), which likely is associated with forest fires. Low EBC concentrations are related to transport from the surrounding seas, e.g. the Arctic Ocean, Davis Strait and the Norwegian Sea (Fig. 6g). In fall, increased $R_{90}$ values are associated with transport from Eastern Europe, North-Central Eurasia and North-Eastern Canada (Fig. 6d) while the bottom decile of the EBC measurement data are related to transport from the North Atlantic Ocean and Baffin Bay (Fig. 6h). The increased $R_{90}$ values over the Greenland glacial ice sheet during all seasons might be associated with local contamination or descent of aged EBC-rich air from higher levels of the atmosphere, which are likely to be in the footprint layer over the ice sheet.

\section{Discussion}

In summer, $R_{90}$ maxima are seen above regions with frequent boreal forest fires, which seem to be the major source of EBC during that season. Elsewhere, $R_{90}$ values are below 0.1 almost everywhere for all stations (in particular for Barrow). In the summer, the Arctic front retreats so far to the north that the Arctic stations see very little direct low-level transport from the surrounding continents. In addition, scavenging processes in the Arctic boundary layer are very efficient because of frequent drizzle (Stohl, 2006). Thus, episodes of high EBC values observed in summer are often associated with air masses that have had almost no surface contact and have instead descended from the free troposphere. As airborne campaigns in the 1980s (Brock et al., 1989) and more recently during POLARCAT have shown, free tropospheric air masses in the Arctic are rich in fire emissions (Warneke et al., 2009; Engvall et al., 2009; Paris et al., 2009). Intense fires can inject pollution directly into the free troposphere and even into the low stratosphere (Fromm et al., 2005) and, thus, would not necessarily be detectable as sources in the $R_{90}$ fields, which are based on footprint emission sensitivities. However, contributions from aged anthropogenic emissions that have been emitted more than 20 days before the measurement may also contribute to an enhanced EBC background that arrives at the stations via the free troposphere.

During seasons other than summer, Northern Eurasia is the dominant EBC source region for all seasons and all stations except Summit. No clear indication of EBC transport from South East Asia can be seen. This is in contrast to some model studies, which attribute a large fraction of BC to South Asia even for the Arctic surface (Koch and Hansen, 2005). Also no influence from North America could be detected, 


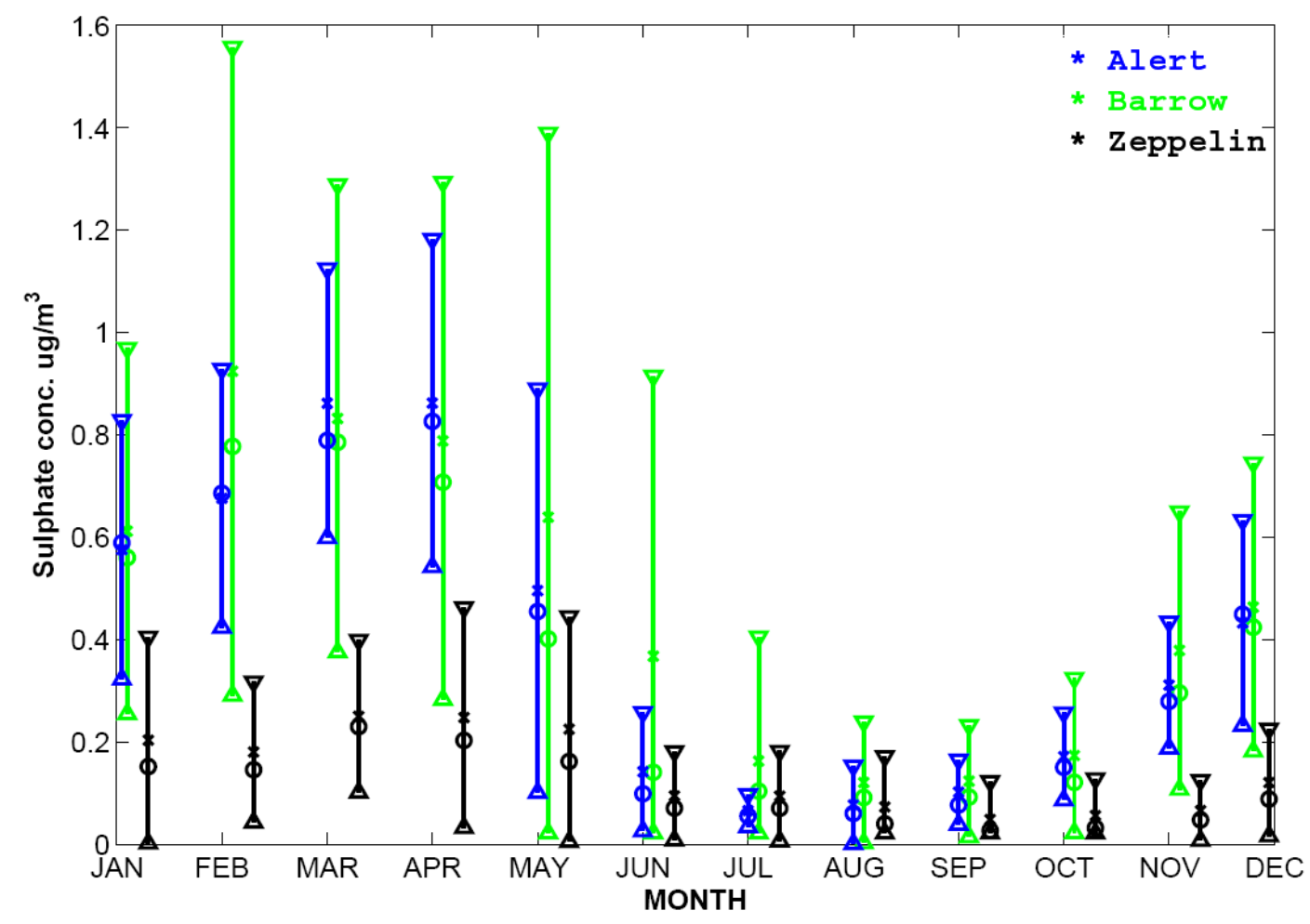

Fig. 7. Monthly averaged concentrations of non-sea-salt sulphate at Alert (blue), Barrow (green) and Zeppelin (black) during the years 2000-2006. The mean concentration is marked with a cross, the median with a circle and the bars indicate variance of \pm 1 standard deviation. Notice that symbols for Barrow and Zeppelin are slightly offset in time for clarify of presentation.

except for Barrow during the fall when there is some influence from southerly sources in Alaska and for Summit in spring and fall. The apparent lack of influence from North America seen at Barrow might not be entirely representative for this part of the Arctic since episodes with direct transport from most North American source regions have mostly been removed by the data screening to avoid local contamination. However, the results for the other stations confirm the overall small influence of North America anthropogenic sources on the Arctic EBC concentrations.

One important question is to what extent the results depend on the choice of a particular percentile threshold. In the appendix, we show for one example that our results are robust against changes in that threshold, and that an alternative method using all the data gives consistent results. This holds for all stations and all parameters studied.

\subsubsection{Sulphate}

Monthly mean concentrations of sulphate measured at all three stations show a clear minimum in late summer to early fall (Fig. 7), which is due to more effective scavenging processes and the northward retreat of the Arctic front, as already discussed for EBC. The annual mean concentrations of non-sea-salt (NSS) sulphate at Alert $\left(0.40 \mu \mathrm{g} \mathrm{m}^{-3}\right)$ and Barrow $\left(0.47 \mu \mathrm{g} \mathrm{m}^{-3}\right)$, are roughly three times as high as the an- nual mean concentration at Zeppelin $\left(0.14 \mu \mathrm{g} \mathrm{m}^{-3}\right)$. The difference is largest from October until May and is most likely the result of a stronger impact of wet scavenging at the Zeppelin station, which is influenced by low pressure systems arriving from the North Atlantic Ocean. To a limited extent, differences may also reflect the different particle size cut-offs used for sampling aerosol on the filters at the various stations.

For the Zeppelin station, $R_{90}$ values are enhanced over northern Eurasia throughout the year (Fig. 8). During winter (Fig. 8 a), $R_{90}$ values are moderately enhanced throughout northern Eurasia. During the summer when the Arctic front has retreated furthest north and the lower Arctic atmosphere is nearly closed off from continental influence, high values of $R_{90}$ are observed only over Scandinavia and the northern region of Russia (Fig. 8c). In all seasons except for winter, there are two $R_{90}$ maxima: one over Eastern Europe and the other over Central Siberia. This distribution of sources is consistent with the sulphur sources for the Arctic identified in a numerical model study by Iversen (1989). The first maximum indicates transport of sulphate-rich air from Eastern Europe and particularly the Kola Peninsula, whereas the second maximum appears to be due primarily to transport from the metal smelting industry in Norilsk. Norilsk stands out as the worldwide strongest maximum in maps of satellite-observed sulphur dioxide total columns (Khokhar et 

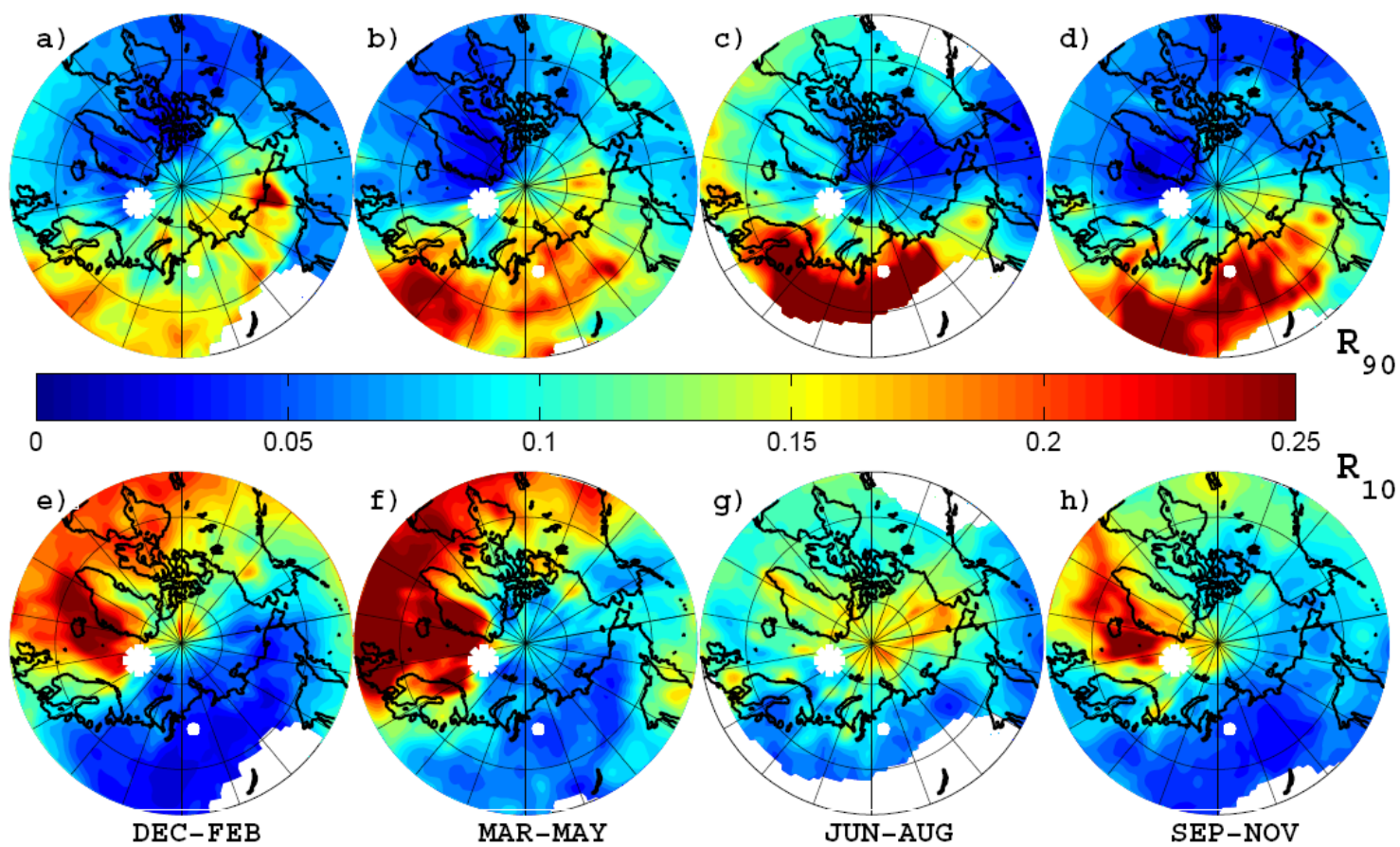

Fig. 8. Fields of $R_{90}$ (top row) and $R_{10}$ (bottom row) for non-sea-salt sulphate measured at the Zeppelin station during the years $2000-2006$, for December-February (far left column), March-May (middle left column), June-August (middle right column) and September-November (far right column). The location of the Zeppelin station is marked by a large white asterisk, and a small white dot marks the location of the industrialized city of Norilsk. White areas have been excluded from the analysis because $S_{\mathrm{T}}$ is too low.

al., 2005). It is likely that this strong but distant point source cannot be fully resolved by our method. Possibly most of the $R_{90}$ enhancements over central Siberia might actually be associated with transport from Norilsk.

High $R_{10}$ values for Zeppelin are found over ocean areas throughout the year (Fig. 8e-h), especially over the North Atlantic where wet scavenging by precipitation is most efficient. At the same time, no high $R_{90}$ values are found over North America, confirming that NSS sulphate originating from there gets scavenged before reaching the European Arctic (Rahn, 1982). In summer, $R_{10}$ values are also high over the Arctic Ocean, indicating sulphate removal by scavenging processes (Behrenfeldt et al., 2008). The results shown in Fig. 8 are not sensitive to changes of the percentile threshold as shown in the appendix.

At Alert (Fig. 9), the time resolution of the sulphate measurements is 7 days. The coarse time resolution impacts the transport analysis by making it difficult to detect individual transport events. As a result, source regions are not well demarcated. Nevertheless, high $R_{90}$ values can be found over Norilsk in spring and summer (Fig. 9b, c). In winter, the $R_{90}$ maximum is displaced slightly to the east of Norilsk, and transport of high sulphate concentrations from Eastern Europe is indicated as well (Fig. 9a). The maximum over north-western Canada cannot easily be explained but might be related to oil production activities. In fall (Fig. 9d), the highest $R_{90}$ values are found over eastern Asia, probably indicating some influence from emissions in China and/or from volcanoes on the Kamchatka Peninsula. Note that transport even from north-eastern China is too infrequent on the 20day time scale of FLEXPART calculations to be resolved in these statistics.

At Barrow (Fig. 10), the time resolution of the measurements ranges from 1 to 5 days, with shortest sampling durations used during the Arctic haze season in spring. Throughout the year, $R_{90}$ values are elevated in the vicinity of Norilsk, again indicating the importance of this source for the entire Arctic. Transport from Eastern Europe also causes high sulphate concentrations at Barrow throughout the year (Fig. 10a-d). The maximum over south-western Canada in spring corresponds well with the location of the great oil sand fields in Alberta, and its large petroleum industry. In summer, high $R_{90}$ values can be found from eastern Asia across the entire northern North Pacific Ocean (Fig. 10c). This might indicate an influence from anthropogenic emissions in Asia or from ships travelling between North America and Asia (Dalsøren et al., 2007). Another possible source is volcanic emissions on Kamchatka and the Aleutian Islands. Notice that smaller $R_{90}$ maxima over the Aleutian Islands can be found also during other times of the year, for instance in spring (Fig. 10b). 

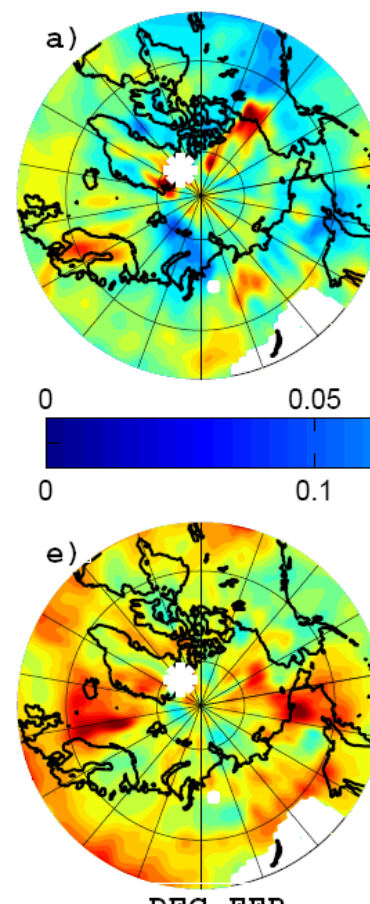

DEC-FEB

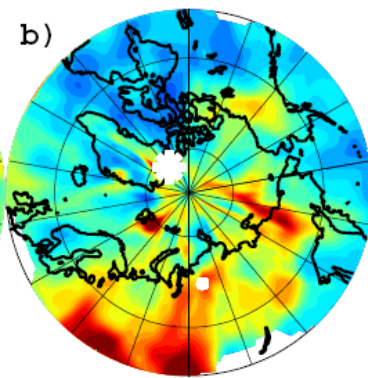

0.1

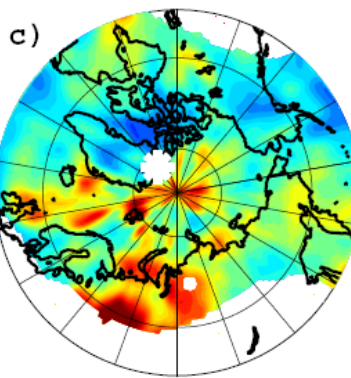

0.15

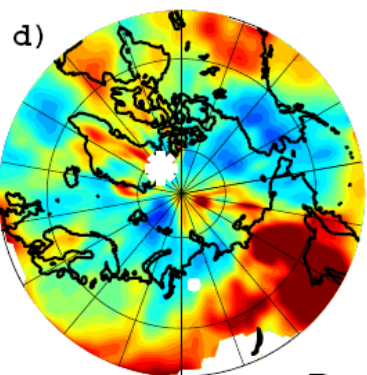

0.2
$0.25 \mathrm{R}_{90}$

$\mathrm{R}_{10}$
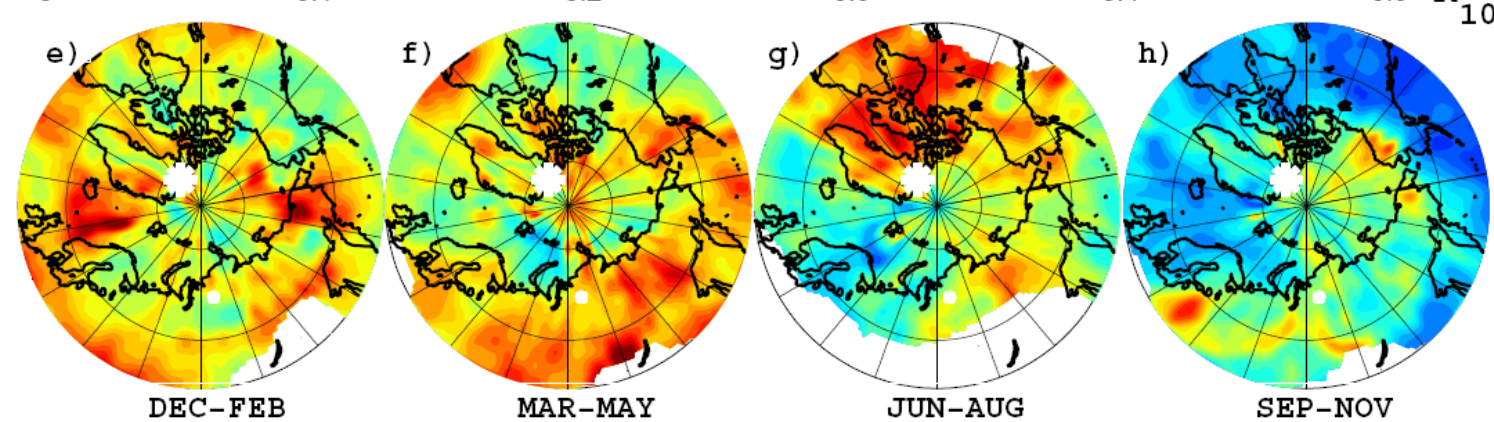

Fig. 9. Same as Fig. 8 but for the Alert station. The upper scale on the colour bar applies to panels (a-d), and the lower scale applies to panels (e-h).
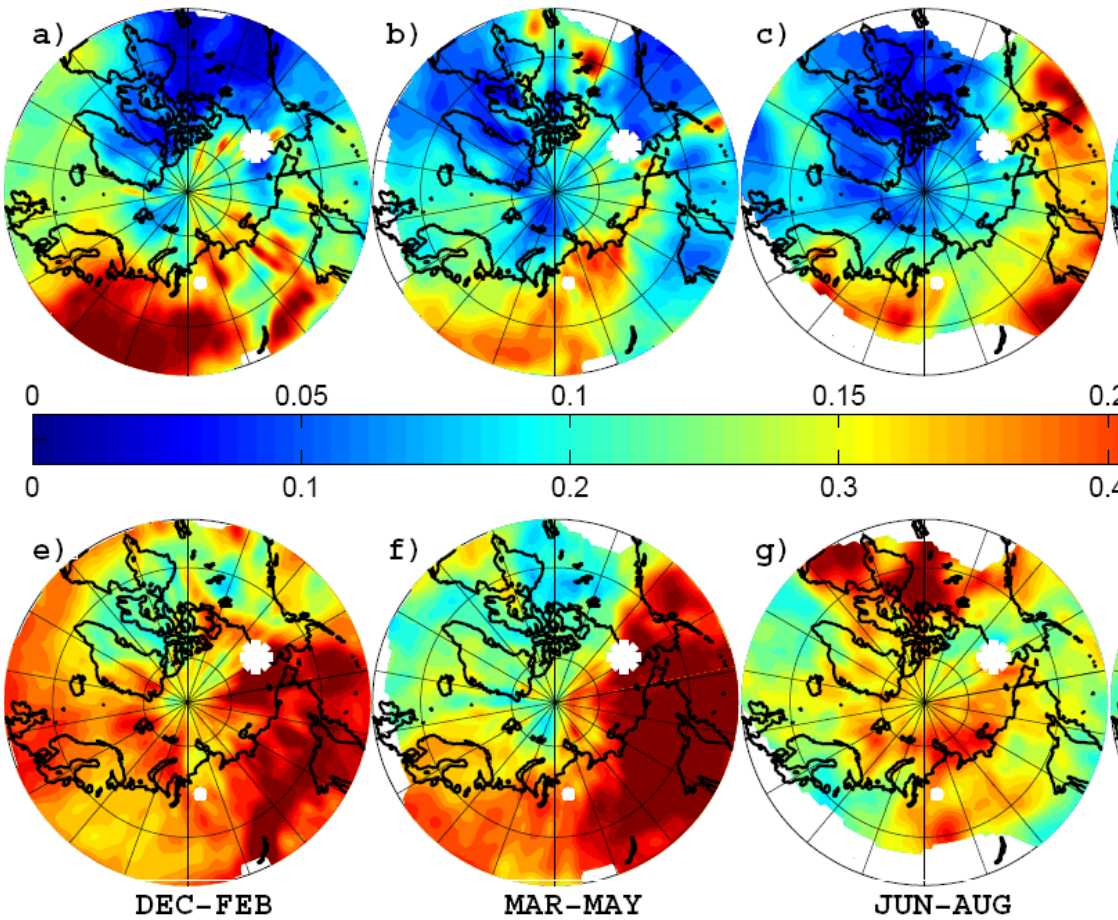

0.1

0.15

0.2

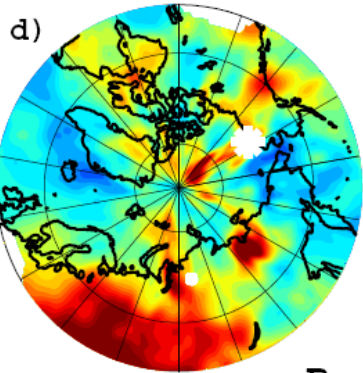

0.2
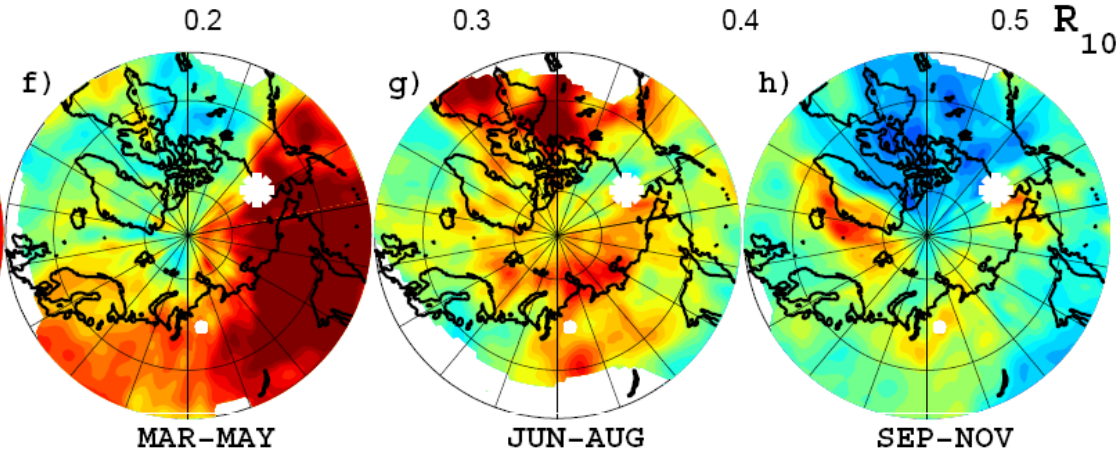

Fig. 10. Same as Fig. 8 but for the Barrow station. The upper scale on the colour bar applies to panels (a-d), and the lower scale applies to panels (e-h). 


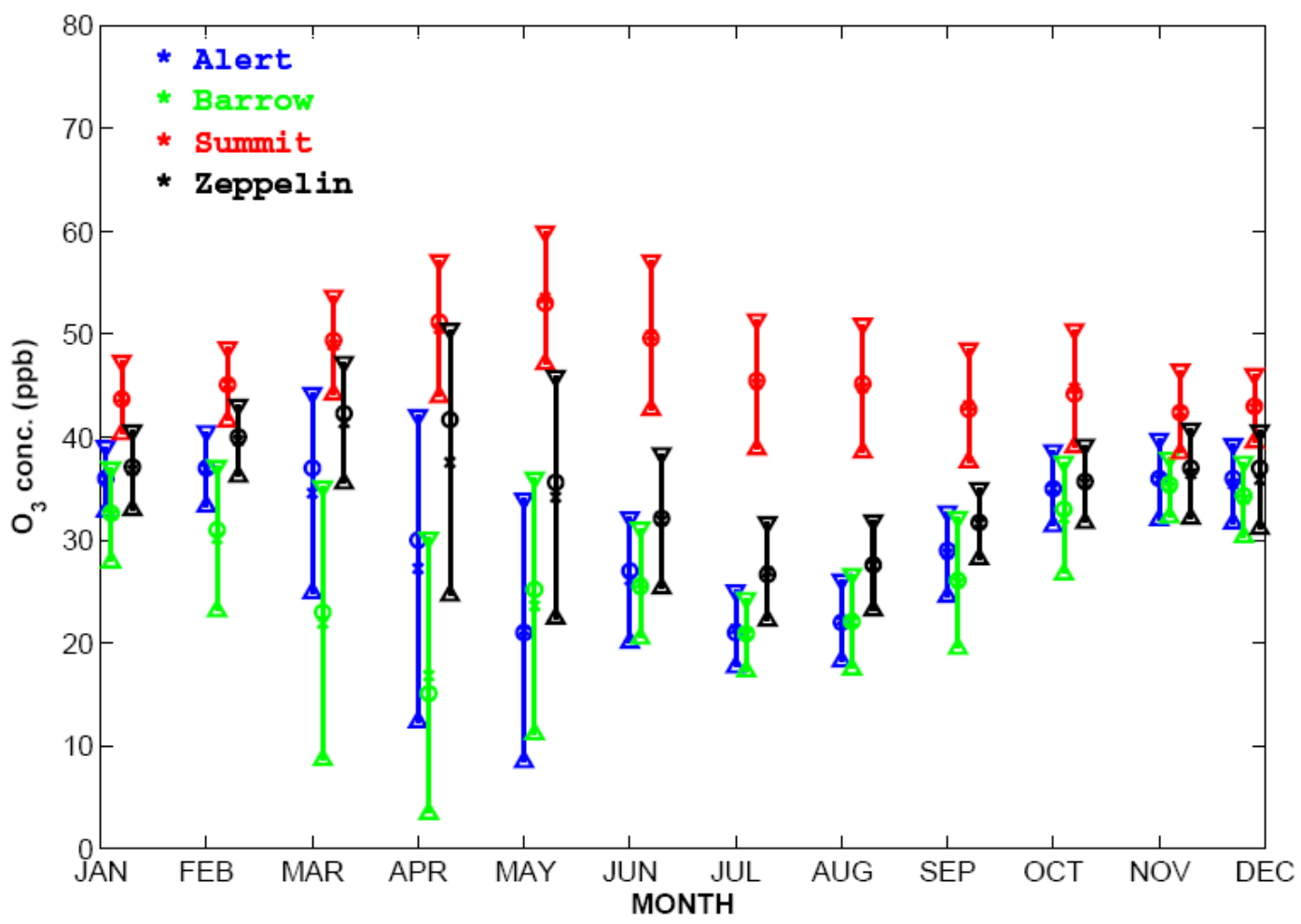

Fig. 11. Monthly ozone at Alert (blue), Barrow (green), Summit (red) and Zeppelin (black) during the years 2000-2007 (2000-2006 for Barrow). The mean concentration is marked with a cross, the median with a circle and the bars indicate the range \pm 1 standard deviation. Notice that symbols for Barrow, Summit and Zeppelin are slightly offset in time for clarify of presentation.

\subsubsection{Light scattering aerosols}

Since light scattering aerosol data were only available for one station (Barrow), results will only be briefly discussed here. For the lowest decile of the data (not shown), the $R_{10}$ patterns are very similar to those for EBC during winter and spring (see Fig. 5e, f), while the patterns during summer and fall are more pronounced over source free regions such as the Hudson Bay and the North Pacific Ocean. For the $R_{90}$ values, in spring results are similar to EBC with increased $R_{90}$ values over North-Central Eurasia and in summer with a pronounced source region associated with the boreal forest fires (not shown). In winter increased $R_{90}$ values are associated with transport from the southern parts of Canada. During all times of the year, the increased $R_{90}$ values are found along the coastline of eastern Alaska and western Canada. Surprisingly, these maxima are not at all identified for the NSS sulphate data, probably indicating that much of the light scattering is caused by organic aerosols. According to the $R_{90}$ results, possible sources for these light-scattering aerosols include oil extracting facilities at Prudhoe Bay and in western Canada, as well as the Smoking Hills (Radke and Hobbs, 1989), a continuous source of smoke. However, as discussed in Sect. 3.2.1, the extensive screening of the Barrow aerosol data could also affect the analysis.

\subsubsection{Ozone}

Hirdman et al. (2009) already have presented an $\mathrm{O}_{3}$ source region analysis for Zeppelin. However, Hirdman et al. (2009) studied mercury and discussed $\mathrm{O}_{3}$ results only briefly to support the mercury analysis. In this paper, we present a full statistical analysis of $\mathrm{O}_{3}$ for all four observatories. Annual mean $\mathrm{O}_{3}$ concentrations increase with the station's altitude: $26.7 \pm 9.9$ for Barrow (11 m a.s.1.), $30.1 \pm 8.9$ for Alert (210 $\mathrm{m}$ a.s.1.), $34.6 \pm 7.6$ for Zeppelin ( $478 \mathrm{~m}$ a.s.l.), and $46.3 \pm 7.3 \mathrm{ppb}$ for Summit (3208 m a.s.1.). These concentrations are in good agreement with earlier reports (Oltmans et al., 2006; Helmig et al., 2007b). The vertical gradient is indicative of a high-altitude source and a low-altitude sink of $\mathrm{O}_{3}$. Seasonal variations are also different (Fig. 11): Summit shows a maximum in late spring, which may be indicative of a stratospheric source peaking at this time of the year (Helmig et al., 2007b). In spite of that, the TOPSE campaign also revealed strong photochemical activity in spring (Browell et al., 2003). In contrast, concentrations at Barrow and Alert are lowest at this time of the year, related to $\mathrm{O}_{3}$ depletion events (see below). All stations show low values in summer when the Arctic lower troposphere is most isolated both from mid-latitude precursor sources and from the stratosphere. 

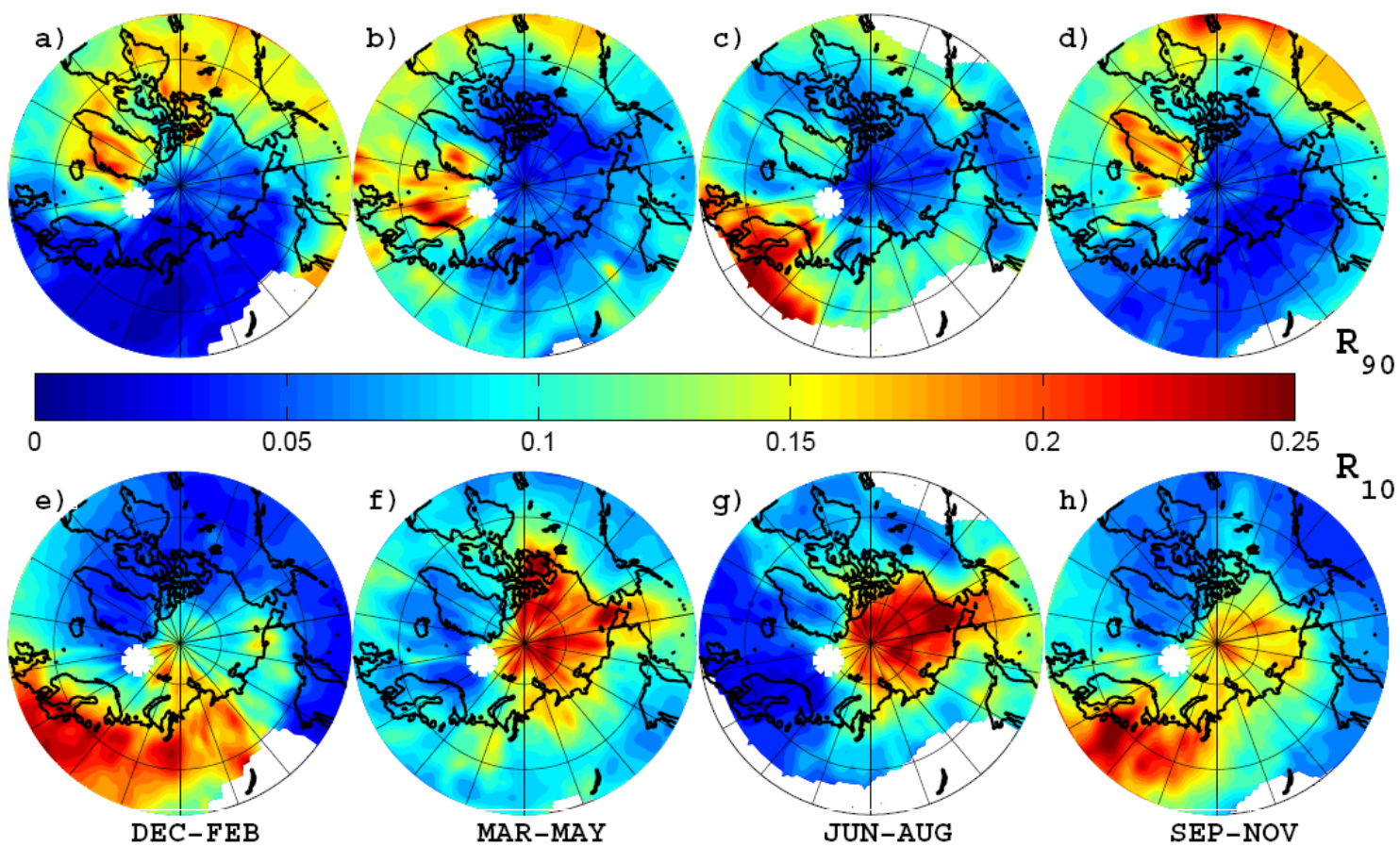

Fig. 12. Fields of $R_{90}$ (top row) and $R_{10}$ (bottom row) for surface ozone measurements at the Zeppelin station during the years 2000-2007, for December-February (left column), March-May (middle-left column), June-August (middle-right column) and September-November (right column). The location of the Zeppelin station is marked by a white asterisk. White areas have been excluded from the analysis because $S_{\mathrm{T}}$ is too low.

Since $\mathrm{O}_{3}$ is a secondarily formed reactive trace gas, the interpretation of sources and sinks is less direct than for primary species. High $R_{90}$ values may indicate regions of precursor gas emissions, regions of preferential $\mathrm{O}_{3}$ formation or lack of $\mathrm{O}_{3}$ destruction by deposition or titration.

Figure 12 shows the $R_{P}$ fields for high and low $\mathrm{O}_{3}$ events observed at Zeppelin in winter, spring, summer and fall. In winter, $R_{10}$ values are highest over Eurasia (Fig. 12e). There, in the absence of sunlight, $\mathrm{O}_{3}$ is titrated by reaction with nitric oxide emitted from anthropogenic sources (Morin et al., 2008) leading to low $\mathrm{O}_{3}$ concentrations at Zeppelin. $R_{90}$ values are generally well below 0.1 over the regions from where the transport reaching the station is most frequent (see Fig. 1), namely the Arctic Ocean and Eurasia where $R_{90}$ values approach zero (Fig. 12a). Thus, high $\mathrm{O}_{3}$ concentrations are almost never associated with air masses having surface contact (an exception are high $R_{90}$ values found over the remote low latitudes from where transport is infrequent). Instead, the high $\mathrm{O}_{3}$ concentrations are primarily associated with descent of air masses from above the boundary layer, which have no surface contact prior to arrival. The high $R_{90}$ values over the elevated topography of Greenland in Fig. 12a also show the downward transport from the free troposphere (Fig. 1a).

In spring, $R_{10}$ values are highest within the Arctic Ocean basin (Fig. 12f), in agreement with earlier studies (Solberg et al., 1996; Eneroth et al., 2007; Bottenheim et al., 2009). Notice the strong decrease in the $R_{10}$ values following almost exactly the coastlines. The high $R_{10}$ values over the Arctic Ocean coincide well with the regions where satellites observe high concentrations of bromine monoxide $(\mathrm{BrO})$ (Simpson et al., 2007), suggesting that the low $\mathrm{O}_{3}$ values are caused primarily by ozone depletion events (ODEs) during the polar sunrise (Barrie et al., 1988; Anlauf et al., 1994; Bottenheim et al., 1990, 2002, 2009). Hirdman et al. (2009) found the same pattern for gaseous elemental mercury (GEM), which also reacts with $\mathrm{Br}$ and $\mathrm{BrO}$, indicating a common sink process for $\mathrm{O}_{3}$ and GEM. As in winter, the $R_{90}$ values along the major transport pathways are well below 0.1 (Fig. 12b), indicating little surface contact except for air masses descending from Greenland. High $R_{90}$ values just off Scandinavia might indicate transport of photochemically formed $\mathrm{O}_{3}$ from $\mathrm{Eu}-$ rope.

In summer, high $R_{90}$ values for $\mathrm{O}_{3}$ can be found over the continental land masses (Fig. 12c), especially Europe, highlighting the importance of photochemical $\mathrm{O}_{3}$ formation (Honrath et al., 2004). Notice in particular the sharp contrast to the winter situation when titration by nitric oxide emissions destroys the $\mathrm{O}_{3}$ in this region (Fig. 12e). $R_{10}$ values are still the highest in oceanic air masses, indicating that the Arctic lower troposphere continues to act as an $\mathrm{O}_{3}$ sink in summer (Fig. 12g). In fact, ODEs with $\mathrm{O}_{3}<10 \mathrm{ppb}$ do occur 

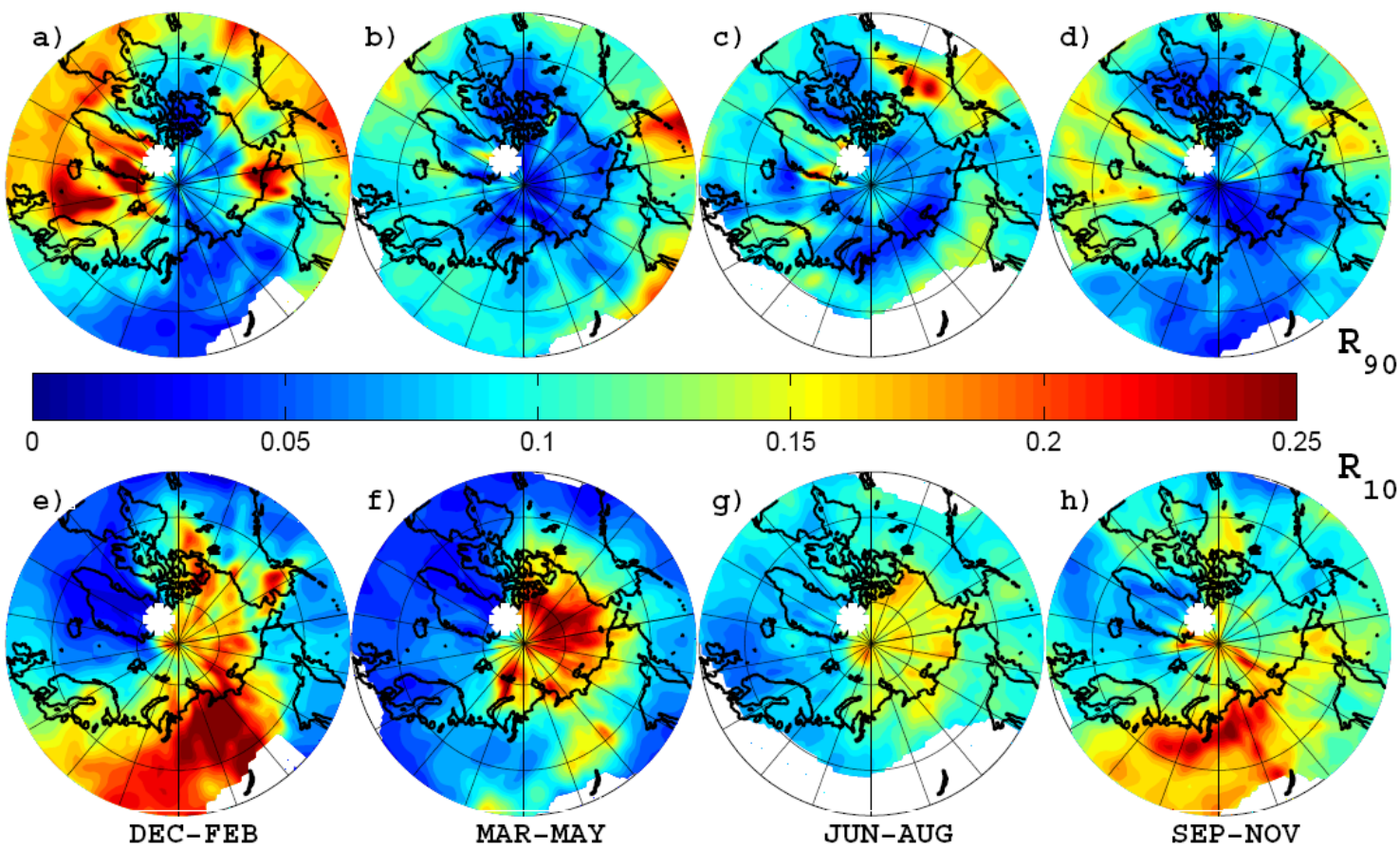

Fig. 13. Same as Fig. 12 but for the Alert station during the years 2000-2007.

at Zeppelin occasionally in early summer, which is in agreement with recent measurements on board of a trans-polar drifting station (Bottenheim et al., 2009).

Fall (Fig. 12d, h) is a time of transition. $R_{10}$ values are elevated both over the Arctic Ocean alike to spring and summer but also over Eurasia, indicating the return to winter-time $\mathrm{O}_{3}$ titration. The $R_{90}$ patterns do already show strong similarities with the winter conditions.

The results for Alert (Fig. 13) are similar to those for Zeppelin (Fig. 12). However there are two main differences. First of all, Europe does not act as a source for anthropogenic $\mathrm{O}_{3}$ formation during summer, but instead there are strongly enhanced $R_{90}$ values over north-western Canada where the country's greatest petroleum production fields from oil sand are located (Fig. 13c). This region also experiences frequent forest fires, which can lead to substantial $\mathrm{O}_{3}$ formation (Wotawa and Trainer, 2000; Forster et al., 2001). Secondly the $R_{90}$ values (Fig. 13a, b, d) show a stronger influence coming from the North Atlantic and North Pacific Oceans than for Zeppelin.

At Barrow, in winter (Fig. 14e) low $\mathrm{O}_{3}$ occurs due to titration mainly over Eurasia and high $\mathrm{O}_{3}$ are generally coupled with transport from the North Pacific Ocean (Fig. 14a). In spring, the low $\mathrm{O}_{3}$ concentrations are again primarily associated with ODEs over the Arctic Ocean (Fig. 14f), while high $R_{90}$ values primarily are found over Eastern Asia and over the North Pacific downwind of Eastern Asia (Fig. 14b). This is consistent with the fact that pollution outflow from Asia has its largest influence on western North America in spring
(Forster et al., 2004). In summer, $\mathrm{O}_{3}$ concentrations in the top decile $\left(R_{90}\right)$ are mainly associated with transport from nearby areas in Alaska/Canada and distant regions in Eurasia (Fig. 14c). The local North American source in Fig. 14c could be associated with $\mathrm{O}_{3}$ formed from anthropogenic precursor emissions from the oil fields at Prudhoe Bay and/or in boreal forest fires. Interestingly, low $\mathrm{O}_{3}$ concentrations in summer are not associated with transport from the Arctic Ocean but instead with transport mainly from the central North Pacific Ocean (Fig. 14g). Correspondingly, no ODEs are observed at Barrow in summer and the lowest measured $\mathrm{O}_{3}$ concentrations are consistent with a North $\mathrm{Pa}$ cific Ocean boundary-layer origin (Watanabe et al., 2005). In fall, high $\mathrm{O}_{3}$ descends mostly from above the boundary layer (Fig. 14d), while the $R_{10}$ patterns mark the transition between summer and winter (Fig. 14h).

At Summit, $R_{90}$ values are well below 0.1 almost everywhere and throughout the year (Fig. 15a-d), confirming that high $\mathrm{O}_{3}$ concentrations are primarily associated with air masses which had little or no surface contact. The exception is transport of photochemically formed $\mathrm{O}_{3}$ from Europe in spring and summer and to some extent also in fall (Fig. 15b, c, d). Transport of photochemical pollution from Europe to Summit is known to occur occasionally (Helmig et al., 2007b). In contrast, the low $\mathrm{O}_{3}$ concentrations at Summit are associated with uplift of air masses from the same regions that cause low- $\mathrm{O}_{3}$ events at the other stations: Eurasia in winter (Fig. 15e), related to titration; the Arctic Ocean in spring (Fig. 15f), related to ODEs; and from both the Arctic 

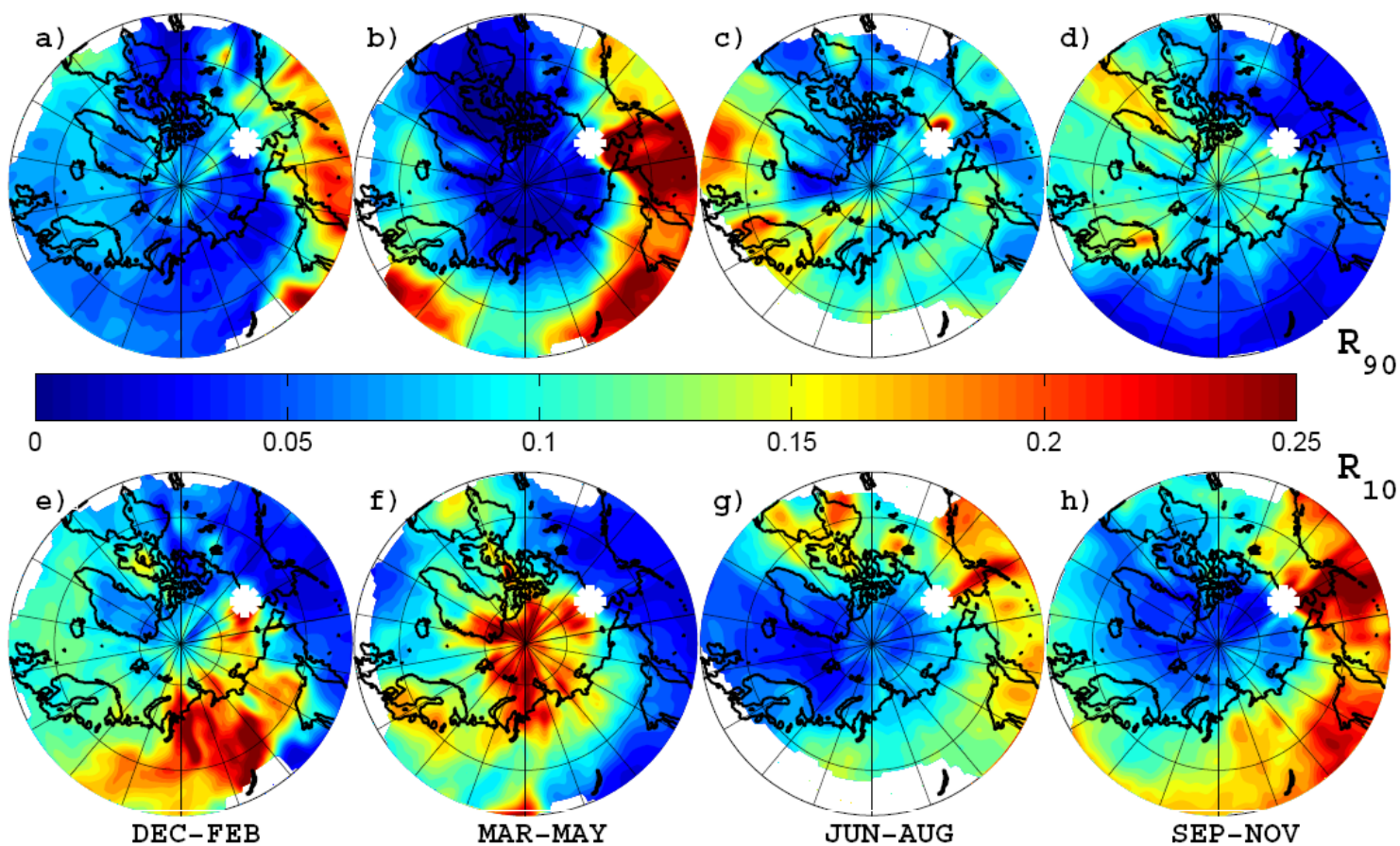

Fig. 14. Same as Fig. 12 but for the Barrow station during the years 2000-2006.
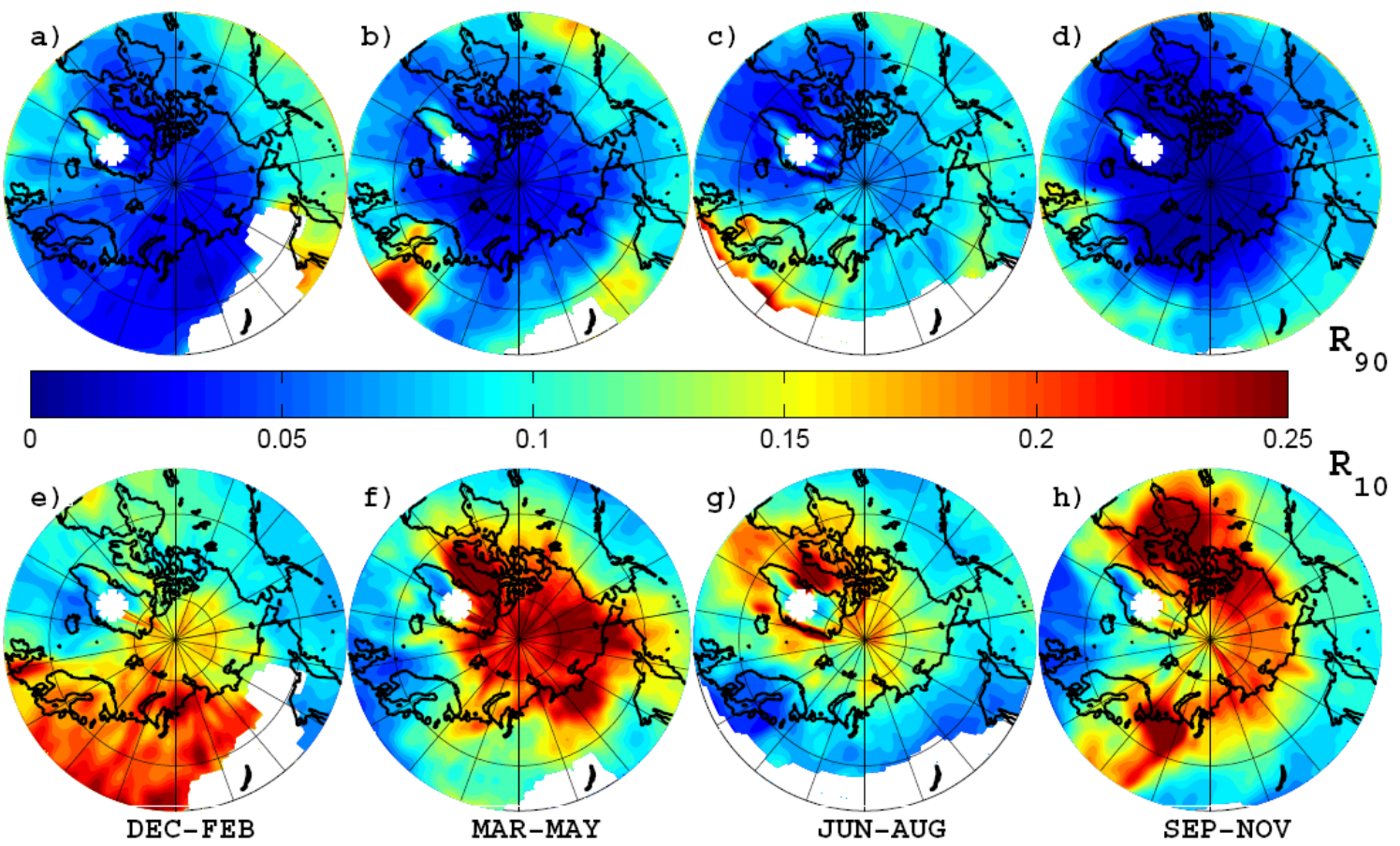

Fig. 15. Same as Fig. 12 but for the Summit station during the years 2000-2007.

Ocean and high-latitude land areas in fall. It is quite remarkable that these surface sinks are well detected even at the high altitude of Summit.
The above analysis shows that at all stations most of the high $\mathrm{O}_{3}$ concentrations occur in air masses having little surface contact, which is suggestive either of a stratospheric source or of a free-tropospheric photochemical source. In 
Table 2. The mean fraction (\%) of air intruding from the stratosphere averaged over 10 and 20 days back in time, for the uppermost and lowermost decile of $\mathrm{O}_{3}$ concentrations, and for the different seasons, as well as the Pearson correlation coefficient $r_{20}$ for the correlation between measured $\mathrm{O}_{3}$ and the fraction of air intruding from the stratosphere averaged over 20 days back in time. All the $r_{20}$ values are statistically significantly different from zero.

\begin{tabular}{|c|c|c|c|c|c|c|c|c|c|c|c|c|c|}
\hline \multirow{2}{*}{$\begin{array}{l}\text { Station } \rightarrow \\
\text { Season } \downarrow\end{array}$} & & \multicolumn{3}{|c|}{ Zeppelin } & \multicolumn{3}{|c|}{ Alert } & \multicolumn{3}{|c|}{ Barrow } & \multicolumn{3}{|c|}{ Summit } \\
\hline & & 10 & 20 & $r_{20}$ & 10 & 20 & $r_{20}$ & 10 & 20 & $r_{20}$ & 10 & 20 & $r_{20}$ \\
\hline \multirow{2}{*}{ Winter } & $\mathrm{High}_{3}$ & 0.0 & 0.9 & \multirow{2}{*}{0.24} & 0.0 & 0.7 & \multirow{2}{*}{0.32} & 0.0 & 0.1 & \multirow{2}{*}{0.15} & 0.4 & 2.2 & \multirow{2}{*}{0.44} \\
\hline & Low $\mathrm{O}_{3}$ & 0.0 & 0.2 & & 0.0 & 0.0 & & 0.0 & 0.0 & & 0.1 & 0.8 & \\
\hline \multirow{2}{*}{ Spring } & High $\mathrm{O}_{3}$ & 0.0 & 0.5 & \multirow[t]{2}{*}{0.54} & 0.0 & 0.6 & \multirow{2}{*}{0.32} & 0.1 & 1.3 & \multirow{2}{*}{0.41} & 2.8 & 5.4 & \multirow{2}{*}{0.38} \\
\hline & Low $\mathrm{O}_{3}$ & 0.0 & 0.0 & & 0.0 & 0.0 & & 0.0 & 0.1 & & 0.2 & 0.5 & \\
\hline \multirow{2}{*}{ Summer } & High $\mathrm{O}_{3}$ & 0.0 & 0.4 & \multirow[t]{2}{*}{0.42} & 0.0 & 0.1 & \multirow{2}{*}{0.20} & 0.0 & 0.1 & \multirow{2}{*}{0.05} & 0.0 & 1.1 & \multirow{2}{*}{0.18} \\
\hline & Low $\mathrm{O}_{3}$ & 0.0 & 0.0 & & 0.0 & 0.0 & & 0.0 & 0.1 & & 0.0 & 0.4 & \\
\hline \multirow{2}{*}{ Fall } & $\mathrm{High}_{3}$ & 0.0 & 0.9 & \multirow[t]{2}{*}{0.34} & 0.4 & 1.0 & \multirow{2}{*}{0.32} & 0.0 & 0.2 & \multirow{2}{*}{-0.18} & 1.9 & 4.5 & \multirow{2}{*}{0.53} \\
\hline & Low $\mathrm{O}_{3}$ & 0.1 & 0.4 & & 0.0 & 0.3 & & 0.2 & 0.9 & & 0.1 & 1.0 & \\
\hline
\end{tabular}

order to quantify the stratospheric influence the fraction of particles which have been transported from above the thermal tropopause to the station as a function of time backward was calculated (with FLEXPART). Table 2 gives the seasonal averages of this stratospheric influence for the different stations averaged over transport times of 10 and 20 days, respectively, and for the $\mathrm{O}_{3}$ concentrations in the top and bottom decile, respectively. For the low-altitude stations (Alert, Barrow, Zeppelin), the fraction of particles arriving from the stratosphere on both time scales is very small (typically $1 \%$ or less even for the 20-days time scale) indicating that the stratospheric influence on Arctic surface air is small on these time scales (Stohl, 2006). The Summit station experiences the largest influence from the stratosphere due to its high-altitude location (3208 $\mathrm{m}$ a.s.1.). At all stations, the stratospheric influence is larger for the high $\mathrm{O}_{3}$ concentrations than for the low $\mathrm{O}_{3}$ concentrations. By calculating Pearson's correlation coefficient $\left(r_{20}\right)$ between measured $\mathrm{O}_{3}$ and the stratospheric influence averaged over 20 days back, a positive correlation for all four stations throughout the year was found (except for Barrow during fall). The correlation normally peaks in spring $\left(r_{20}=0.4 \pm 0.1\right)$ which coincides with the season of the year where the strongest influence from the stratosphere would be expected because of relatively frequent stratospheric intrusions (Stohl, 2006) and high $\mathrm{O}_{3}$ concentrations in the lowermost stratosphere. The correlation shows a relation with the station altitude such that the highest $r_{20}$ values are found for Summit followed by Zeppelin, Alert and last Barrow (Table 2). In summary, while intrusions of stratospheric air are rare on the timescales considered, especially for low-altitude sites, transport from the stratosphere does appear to have a substantial influence on surface $\mathrm{O}_{3}$ concentrations in the Arctic.

\section{Conclusions}

In this paper we have employed a novel method to combine the calculations from a Lagrangian particle dispersion model, FLEXPART, and measurement data from four Arctic stations (Zeppelin, Alert, Barrow and Summit) in a statistical analysis of the source regions of short-lived pollutants. The calculated sensitivities have been normalized to surface emissions when observed pollutant concentrations were in the top (or lowest) decile with the emission sensitivities for the entire data set to reveal the regions from where high (or low) pollutant concentrations originate. The results are robust against changes of the percentile thresholds used. The calculated emission sensitivities have also been used as flow climatologies to reveal the overall air mass origins for the different stations. Our main findings from this study are:

- Transport climatologies based on 20-day backward calculations for Zeppelin, Alert and Barrow show that these stations are highly sensitive to surface emissions in the Arctic. In winter, they are also sensitive to emissions in high-latitude Eurasia, whereas in summer these Arctic surface stations are largely shielded off from continental emissions on the 20-day time scale. Should local sources in the Arctic (e.g., oil and gas drilling, shipping) increase in the future, they would contribute strongly to surface concentrations of pollutants in the Arctic, particularly in summer. Emission sensitivities over southern Asia and southern North America are extremely small throughout the year. The high-altitude station Summit is more than an order of magnitude less sensitive to surface emissions in the Arctic than the lower altitude stations. In contrast, sensitivities to surface emissions in the southern parts of the Northern Hemisphere continents are higher than for the other stations. This shows that potential pollution source regions 

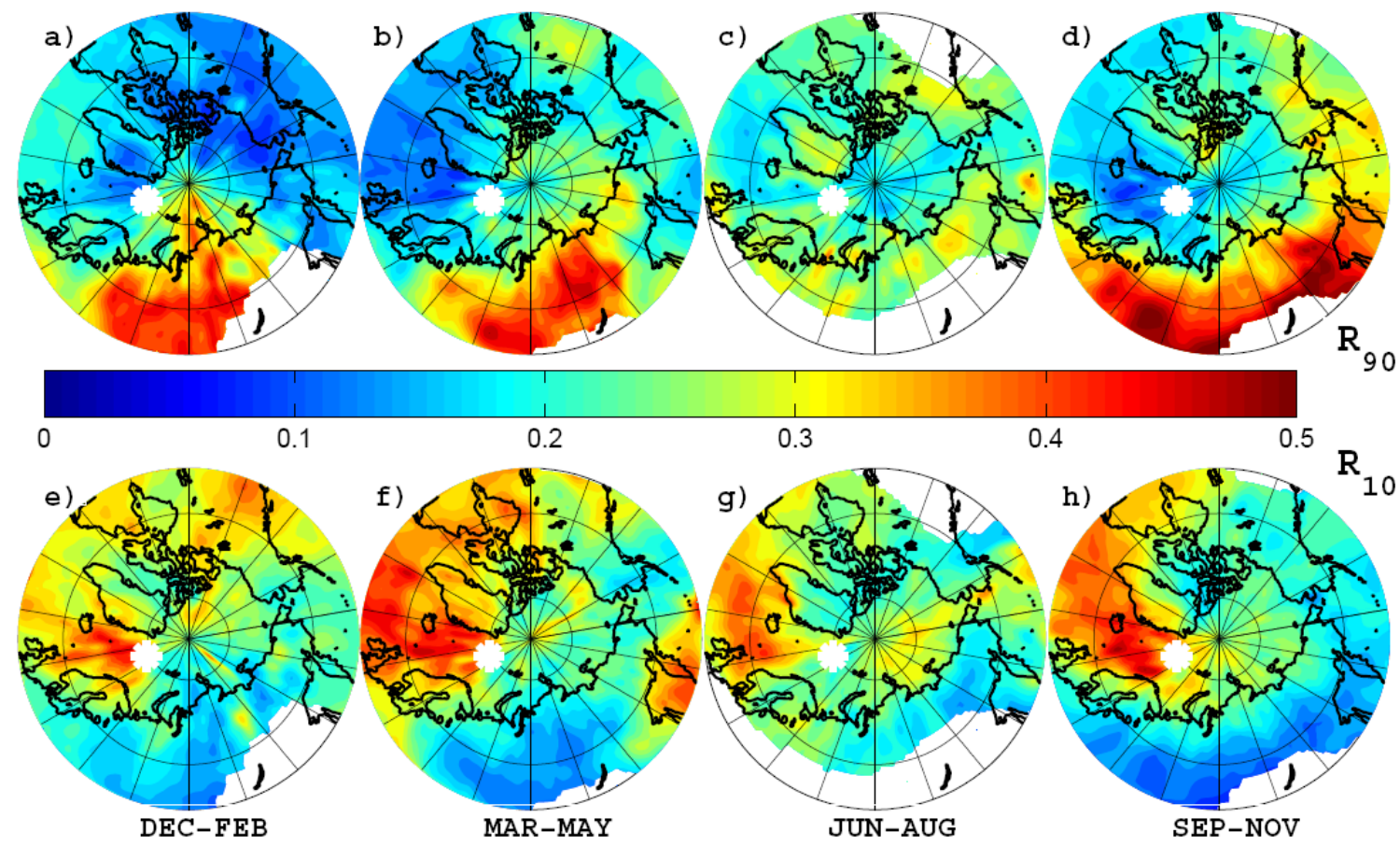
0
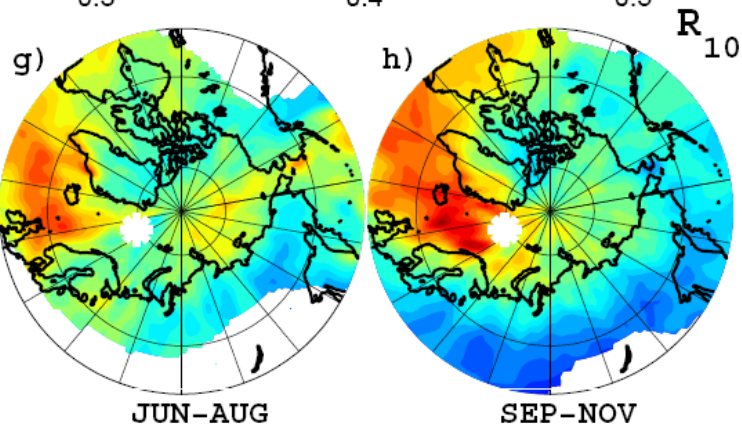

Fig. A1. Fields of $R_{75}$ (top row) and $R_{25}$ (bottom row) for measurements of EBC at the Zeppelin station during the years 2002-2007, for December-February (far left column), March-May (middle left column), June-August (middle right column) and September-November (far right column). The location of the Zeppelin station is marked by a white asterisk. White areas have been excluded from the analysis because $S_{\mathrm{T}}$ is too low.
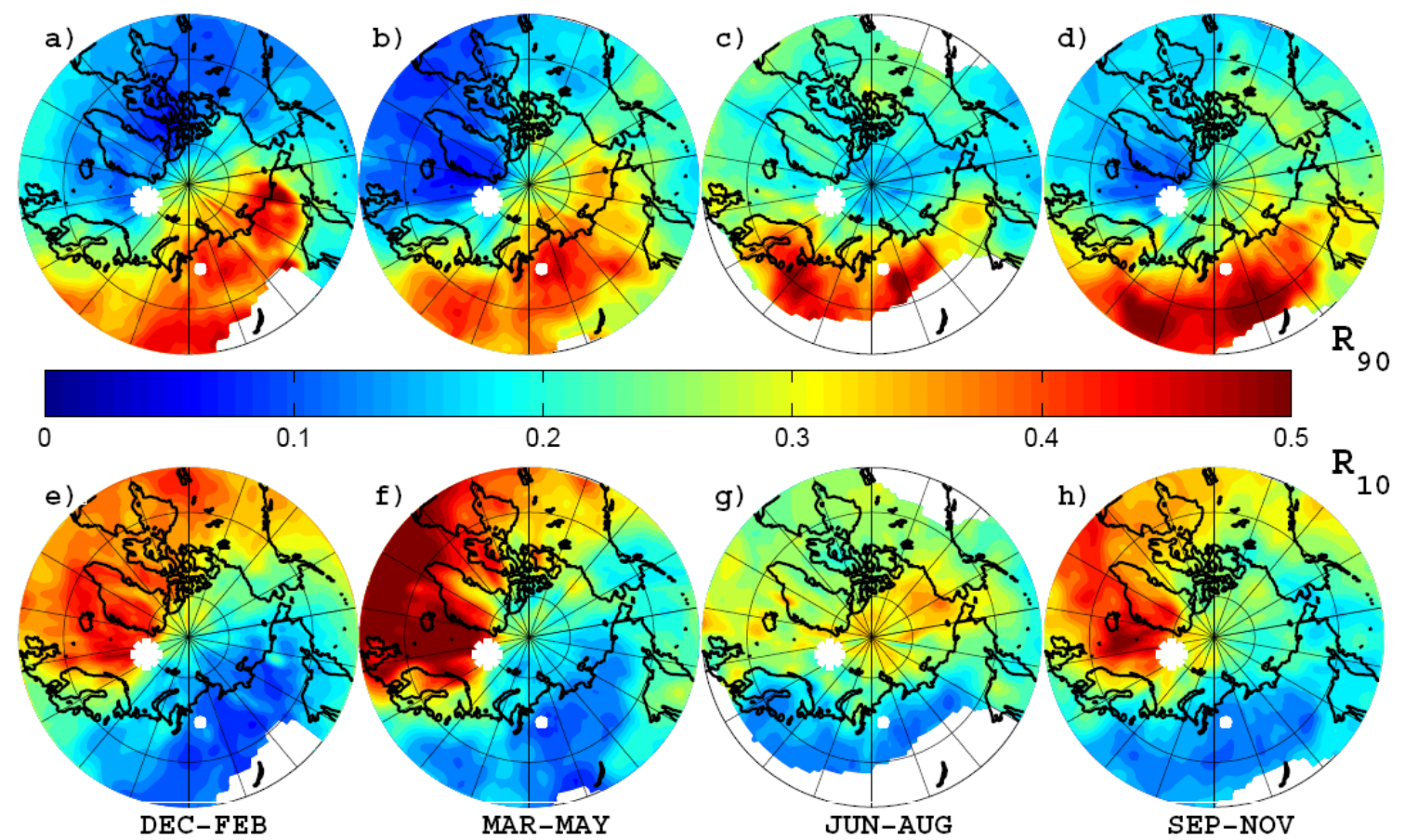

Fig. A2. Fields of $R_{75}$ (top row) and $R_{25}$ (bottom row) for non-sea-salt sulphate measured at the Zeppelin station during the years 2000-2006, for December-February (far left column), March-May (middle left column), June-August (middle right column) and September-November (far right column). The location of the Zeppelin station is marked by a large white asterisk, and a small white dot marks the location of the industrialized city of Norilsk. White areas have been excluded from the analysis because $S_{\mathrm{T}}$ is too low. 

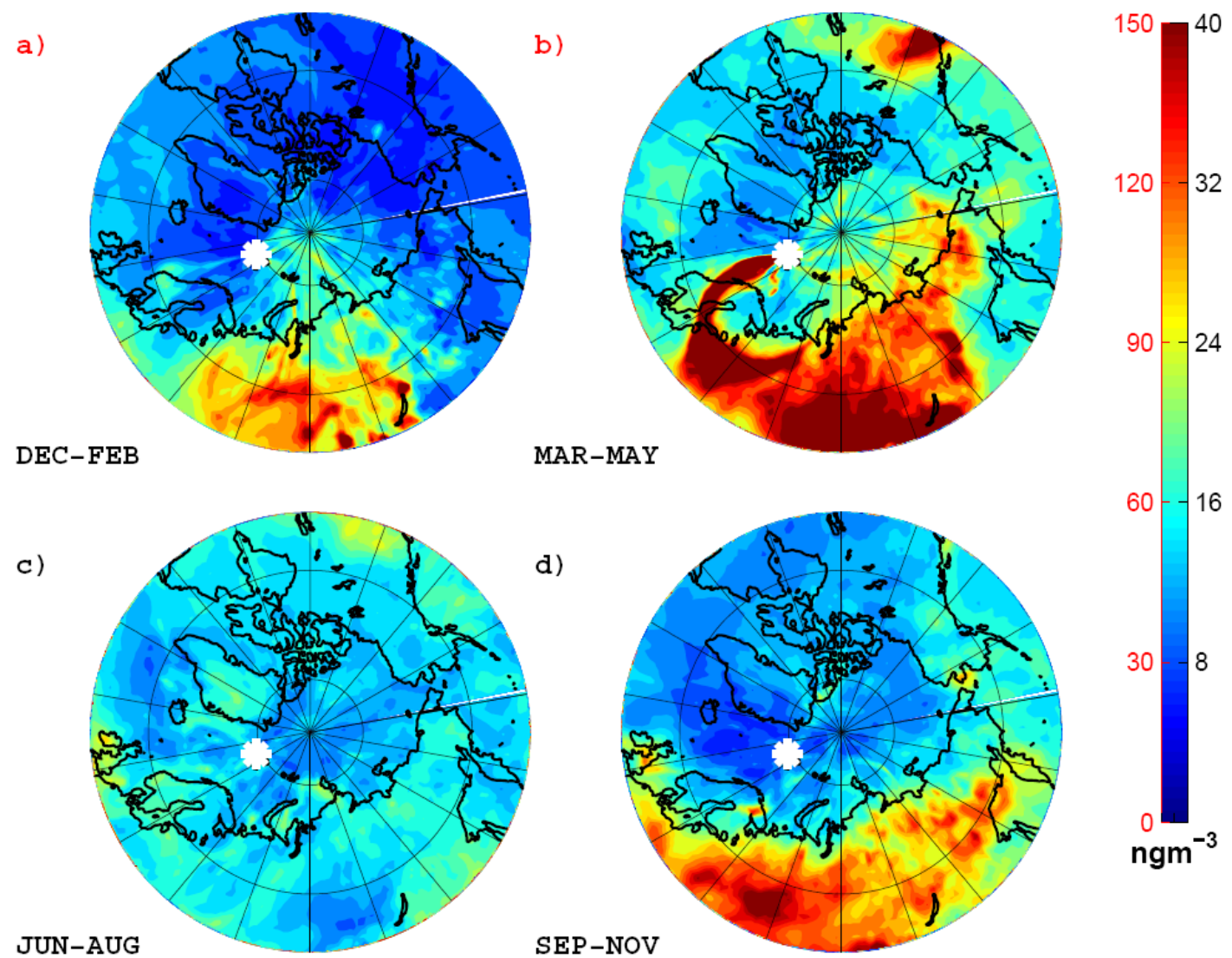

Fig. A3. The complete set of calculated emission sensitivity fields, each weighted with the associated EBC concentrations measured at Zeppelin during the years 2002-2007, for December-February (upper left), March-May (upper right), June-August (lower left) and SeptemberNovember (lower right). The left colour bar applies to panels (a) and (b), right scale applies to panels (c) and (d). The white asterisk marks the location of the Zeppelin station.

for Summit and for ice core sites drilled at similar altitudes are distinctly different from those for the surface stations.

- Equivalent black carbon: at Zeppelin, Alert and Barrow, the top decile of EBC concentrations originate from high-latitude Eurasia throughout the year. Only during summer, there is also evidence for transport of emissions from boreal forest fires in North America to Barrow and Alert and from Siberia to Zeppelin. Furthermore, in summer EBC concentrations are enhanced when the air descends from the free troposphere. This point toward boreal forest fires injecting emissions higher into the atmosphere or aged air masses from unresolved sources beyond the 20-day time scale considered in this study. However, we find no direct evidence that transport from Southern Asia or Southern North America is a source of EBC at the Arctic surface stations.

- Sulphate: As for EBC, the dominant source region for sulphate at Zeppelin, Alert and Barrow is high-latitude Eurasia. There, the sulphate primarily originates from two source regions, Eastern Europe and the metal smelting complexes at Norilsk. At Alert in fall and at Barrow in summer, high sulphate concentrations are also found when the air is transported from Eastern Asia and the North Pacific. This may indicate an anthropogenic source of the sulphate in Eastern Asia, but emissions from volcanoes on Kamchatka and the Aleutian Islands are equally likely sources.

- Light scattering aerosols: Enhanced values of aerosol light scattering at Barrow are associated with boreal forest fires in Alaska and Canada, similar to EBC. Transport from Eurasia also leads to enhanced aerosol light scattering. However, there is no close correspondence between the sources of sulphate and light scattering aerosols. Additional sources of scattering aerosol in Northern Alaska and Canada not seen for sulphate are probably related to organic aerosols from oil drilling activities and/or the Smoking Hills fires.

- Ozone: The annual mean concentrations of $\mathrm{O}_{3}$ increase systematically with altitude from the lowest station, Barrow, to the highest, Summit. This increase is 

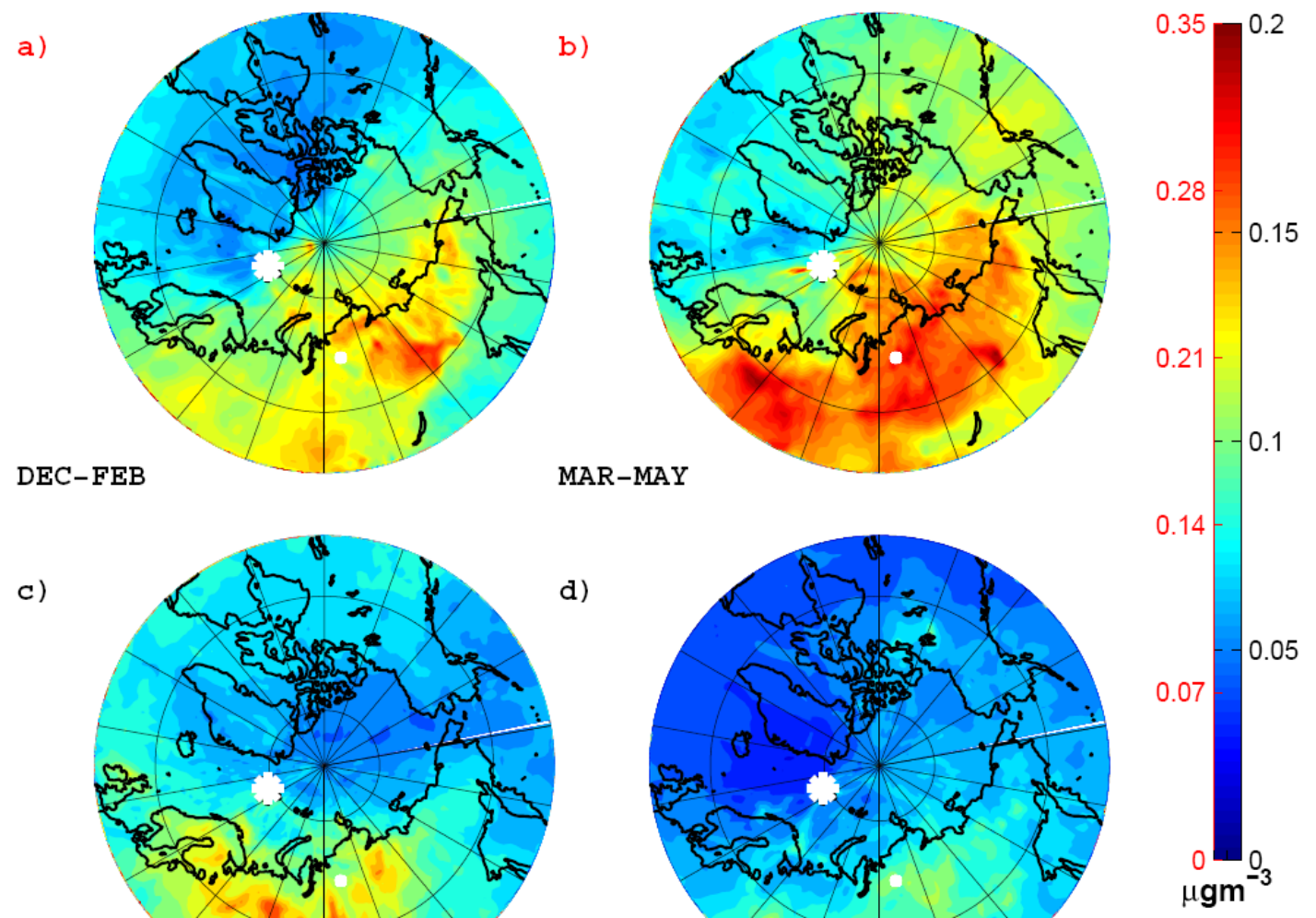

JUN-AUG

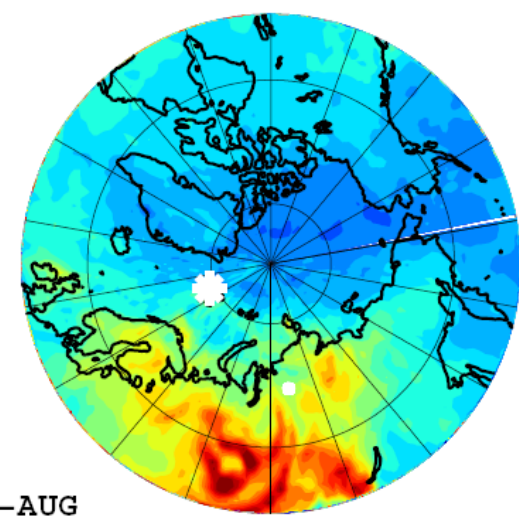

d)

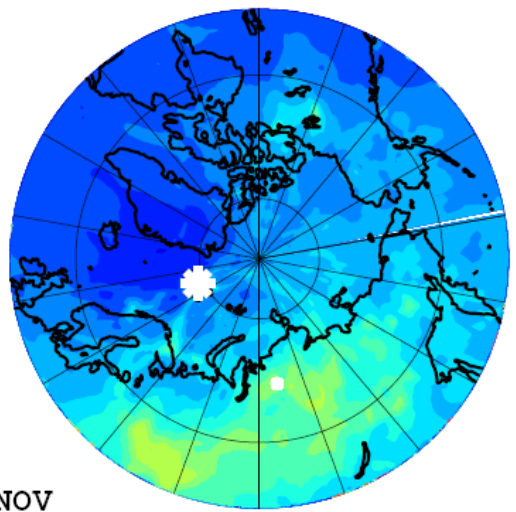

SEP-NOV

Fig. A4. The complete set of calculated emission sensitivity fields, each weighted with the associated NSS sulphate concentrations measured at Zeppelin during the years 2000-2006, for December-February (upper left), March-May (upper right), June-August (lower left) and September-November (lower right). The left colour bar applies to panels (a) and (b), right scale applies to panels (c) and (d). The location of the Zeppelin station is marked by a large white asterisk, and a small white dot marks the location of Norilsk.

accompanied by an increasing fraction of air arriving from the stratosphere and increasing positive correlations between this calculated quantity and the observed $\mathrm{O}_{3}$. Furthermore, at all stations, $\mathrm{O}_{3}$-rich air masses have little surface contact during the previous 20 days. This indicates that while transport from the stratosphere is slow in the Arctic, it nevertheless has a large impact on observed surface $\mathrm{O}_{3}$ throughout the year. When transport occurs from Eurasia, all stations show decreased $\mathrm{O}_{3}$ concentrations in winter (due to titration of $\mathrm{O}_{3}$ by nitric oxide) but enhanced ozone concentrations in summer (due to photochemical $\mathrm{O}_{3}$ formation). When air travels across the Arctic Ocean in spring, all stations show decreased $\mathrm{O}_{3}$ concentrations due to ozone depletion events. Especially for Zeppelin, this pattern continues into summer.

- A harmonization of the sampling instruments and measurements within the Arctic would simplify data comparison significantly and therefore aid similar studies in the future.

\section{Appendix A}

Our method uses particular percentile thresholds (uppermost and lowermost deciles) to compare transport patterns for high and low measured concentrations, respectively, with the total average transport. One possible concern is that the results are sensitive to changes of the percentile thresholds. Here we show, at the examples of EBC (Fig. A1) and NSS sulphate (Fig. A2) for Zeppelin, that this is not the case by using the uppermost and lowermost quartiles instead of deciles. The $R_{75}$ and $R_{25}$ patterns identified are almost the same as the $R_{90}$ and $R_{10}$ patterns shown in Figs. 3 and 8.

An alternative method was also tested, similar to the one used by Seibert et al. (1994) and Stohl et al. (1996) for trajectory statistics. With this method, $S$ values are weighted by the corresponding measured concentration $c(m)$.

$C(i, j)=\frac{\sum_{m=1}^{M} c(m) S(i, j, m)}{\sum_{m=1}^{M} S(i, j, m)}$

High values of $C(i, j)$ indicate that transport through grid cell $(i, j)$ is preferentially associated with high measured concentrations and, thus, grid cell $(i, j)$ is a potential source 
of the measured parameter. This method has the advantage of not being focussed on the distribution tails. Figures A3 and A4 show that sources identified with this method are similar to those identified with the percentile method.

Acknowledgements. We appreciate discussions with C. Brock and T. Ryerson on Alaskan emissions. We thank the two anonymous reviewers for their comments on our paper. We would like to thank ECMWF and met.no for access to the ECMWF archives. We would also like to thank the Global Monitoring Division at NOAA Earth System Research Laboratory, the Atmospheric Science and Technology Directorate at Environment Canada and SFT Norway for providing data. The Swedish Environmental Protection Agency and the Swedish Research Council have sponsored BC measurements at Zeppelin. Funding for this study was provided by the Norwegian Research Council through the POLARCAT and SUMSVAL projects.

Edited by: J. W. Bottenheim

\section{References}

Aas, W., Solberg, S., Manø, S., and Yttri, K. E.: Monitoring of long range transported air pollutants, annual report for 2007, Norwegian Institute for Air Research, Kjeller, 2008.

Anlauf, K., Mickle, R., and Trivett, N.: Measurement of ozone during polar sunrise experiment 1992, J. Geophys. Res., 99, 2534525353, 1994.

Arnott, W., Hamasha, K., Moosmuller, H., Sheridan, P., and Ogren, J.: Towards aerosol light-absorption measurements with a 7wavelength aethalometer: Evaluation with a photoacoustic instrument and 3-wavelength nephelometer, Aerosol Sci. Technol., 39, 17-29, 2005.

Ashbaugh, L.: A statistical trajectory technique for determining airpollution source regions, Journal of the Air Pollution Control Association, 33, 1096-1098, 1983.

Ashbaugh, L., Malm, W., and Sadeh, W.: A residence time probability analysis of sulfur concentrations at grand-canyon-nationalpark, Atmos. Environ., 19, 1263-1270, 1985.

Barrie, L.: Arctic air-pollution - an overview of current knowledge, Atmos. Environ., 20, 643-663, 1986.

Barrie, L., Bottenheim, J., Schnell, R., Crutzen, P., and Rasmussen, R.: Ozone destruction and photochemical-reactions at polar sunrise in the lower arctic atmosphere, Nature, 334, 138-141, 1988.

Behrenfeldt, U., Krejci, R., Ström, J., and Stohl, A.: Chemical properties of Arctic aerosol particles collected at Zeppelin station during the aerosol transition period in May and June of 2004, Tellus B, 60, 405-415, 2008.

Bodhaine, B. A.: Aerosol absorption measurements at Barrow, Mauna Loa and the South Pole, J. Geophys. Res., 100, 89678975, 1995.

Bond, T., Anderson, T., and Campbell, D.: Calibration and intercomparison of filter-based measurements of visible light absorption by aerosols, Aerosol Sci. Technol., 30, 582-600, 1999.

Bond, T. and Bergstrom, R.: Light absorption by carbonaceous particles: An investigative review, Aerosol Sci. Technol., 40, 27-67, 2006.

Bottenheim, J., Barrie, L., Atlas, E., Heidt, L., Niki, H., Rasmussen, R., and Shepson, P.: Depletion of lower tropospheric ozone dur- ing Arctic spring - the polar sunrise experiment 1988, J. Geophys. Res., 95, 18555-18568, 1990.

Bottenheim, J., Fuentes, J., Tarasick, D., and Anlauf, K.: Ozone in the Arctic lower troposphere during winter and spring 2000 (Alert2000), Atmos. Environ., 36, 2535-2544, 2002.

Bottenheim, J. W., Netcheva, S., Morin, S., and Nghiem, S. V.: Ozone in the boundary layer air over the Arctic Ocean: measurements during the TARA transpolar drift 2006-2008, Atmos. Chem. Phys., 9, 4545-4557, 2009, http://www.atmos-chem-phys.net/9/4545/2009/.

Brock, C. A., Radke, L. F., Lyons, J. H., and Hobbs, P. V.: Arctic hazes in summer over Greenland and the North American Arctic. I: Incidence and origins, J. Atmos. Chem., 9, 129-148, 1989.

Browell, E. V., Hair, J. W., Butler, C. F., Grant, W. B., Deyoung, R. J., Fenn, M. A., et al.: Ozone, aerosol, potential vorticity, and trace gas trends observed at high-latitudes over North America from February to May 2000, J. Geophys. Res., 108, 8369, doi:10.1029/2002JD003232, 2003.

Carlson, T.: Speculations on the movement of polluted air to the Arctic, Atmos. Environ., 15, 1473-1477, 1981.

Dalsøren, S. B., Endresen, Ø., Isaksen, I. S. A., Gravir, G., and Sørgård, E.: Environmental impacts of the expected increase in sea transportation, with a particular focus on oil and gas scenarios for Norway and northwest Russia, J. Geophys. Res., 112, D02310, doi:10.1029/2005JD006927, 2007.

Delene, D. and Ogren, J.: Variability of aerosol optical properties at four North American surface monitoring sites, J. Atmos. Sci., 59, 1135-1150, 2002.

Devore, J. and Farnum, N.: Applied statistics for engineers and scientists, in, Duxbury Press, 315-318, 1999.

Eleftheriadis, K., Vratolis, S., and Nyeki, S.: Aerosol black carbon in the European Arctic: Measurements at Zeppelin station, Ny-Ålesund, Svalbard from 1998-2007, Geophys. Res. Lett., 36, L02809, doi:10.1029/2008GL035741 2009.

Eneroth, K., Kjellstrom, E., and Holmen, K.: A trajectory climatology for Svalbard; investigating how atmospheric flow patterns influence observed tracer concentrations, Phys. Chem. Earth., 28, 1191-1203, 2003.

Eneroth, K., Holmen, K., Berg, T., Schmidbauer, N., and Solberg, S.: Springtime depletion of tropospheric ozone, gaseous elemental mercury and non-methane hydrocarbons in the european arctic, and its relation to atmospheric transport, Atmos. Environ., 41, 8511-8526, 2007.

Engvall, A.-C., Ström, J., Tunved, P., Krejci, R., Schlager, H., and Minikin, A.: The radiative effect of an aged, internally-mixed Arctic aerosol originating from lower-latitude biomass burning, Tellus B, 61, 677-684, 2009.

Flanner, M. G. and Zender, C. S.: Linking snowpack microphysics and albedo evolution, J. Geophys. Res., 111, D12208, doi: 10.1029/2005JD006834, 2006.

Flanner, M. G., Zender, C. S., Randerson, J. T., and Rasch, P. J.: Present-day climate forcing and response from black carbon in snow, J. Geophys. Res., 112, D11202, doi:10.1029/2006JD008003, 2007.

Forster, C., Wandinger, U., Wotawa, G., James, P., Mattis, I., Althausen, D., et al.: Transport of boreal forest fire emissions from Canada to Europe, J. Geophys. Res., 106, 22887-22906, 2001.

Forster, C., Cooper, O., Stohl, A., Eckhardt, S., James, P., Dunlea, E., et al.: Lagrangian transport modell forecasts and a trans- 
port climatology for the Intercontinental Transport and Chemical Transformation 2002 (ITCT 2k2) measurement campaign, J. Geophys. Res., 109, D07S92, doi:10.1029/2003JD003589, 2004.

Forster, C., Stohl, A., and Seibert, P.: Parameterization of convective transport in a lagrangian particle dispersion model and its evaluation, J. Appl. Meteorol. Climatol., 46, 403-422, 2007.

Fromm, M., Bevilacqua, R., Servranckx, R., Rosen, J., Thayer, J., Herman, J., and Larko, D.: Pyro-cumulonimbus injection of smoke to the stratosphere: Observations and impact of a super blowup in northwestern Canada on 3-4 august 1998, J. Geophys. Res., 110, D08205, doi:10.1029/2004JD005350, 2005.

Garrett, T. and Zhao, C.: Increased arctic cloud longwave emissivity associated with pollution from mid-latitudes, Nature, 440, 787789, 2006.

Garrett, T. and Verzella, L.: An evolving history of Arctic aerosols, B. Am. Meteorol. Soc., 89, 299-302, 2008.

Gautier, D. L., Bird, K. J., Charpentier, R. R., Grantz, A., Houseknecht, D. W., Klett, T. R., et al.: Assessment of undiscovered oil and gas in the Arctic, Science, 324, 1175-1179, 2009.

Granier, C., Niemeier, U., Jungclaus, J. H., Emmons, L., Hess, P., Lamarque, J.-F., et al.: Ozone pollution from future ship traffic in the Arctic northern passages, Geophys. Res. Lett., 33, L13807, doi:10.1029/2006GL026180, 2006.

Greenaway, K. R.: Experiences with Arctic flying weather, Royal Meteorological Society Canadian Branch, Toronto, 1950.

Han, Y., Holsen, T., Hopke, P., and Yi, S.: Comparison between back-trajectory based modeling and lagrangian backward dispersion modeling for locating sources of reactive gaseous mercury, Environ. Sci. Technol., 39, 1715-1723, 2005.

Hansen, J. and Nazarenko, L.: Soot climate forcing via snow and ice albedos, P. Natl. Acad. Sci. USA, 101, 423-428, 2004.

Helmig, D., Oltmans, S., Carlson, D., Lamarque, J., Jones, A., Labuschagne, C., et al.: A review of surface ozone in the polar regions, Atmos. Environ., 41, 5138-5161, 2007a.

Helmig, D., Oltmans, S., Morse, T., and Dibb, J.: What is causing high ozone at Summit, Greenland?, Atmos. Environ., 41, 50315043, 2007b.

Hirdman, D., Aspmo, K., Burkhart, J. F., Eckhardt, S., Sodemann, H., and Stohl, A.: Transport of mercury in the Arctic atmosphere: evidence for a spring-time net sink and summer-time source, Geophys. Res. Lett., 36, L12814, doi:10.1029/2009GL038345, 2009.

Honrath, R., Owen, R., Val Martin, M., Reid, J., Lapina, K., Fialho, P., et al: Regional and hemispheric impacts of anthropogenic and biomass burning emissions on summertime co and 03 in the North Atlantic lower free troposphere, J. Geophys. Res., 109, D24310, doi:10.1029/2004JD005147, 2004.

Hoyle, C. R., Berntsen, T., Myhre, G., and Isaksen, I. S. A.: Secondary organic aerosol in the global aerosol - chemical transport model Oslo CTM2, Atmos. Chem. Phys., 7, 5675-5694, 2007, http://www.atmos-chem-phys.net/7/5675/2007/.

Iversen, T. and Joranger, E.: Arctic air-pollution and large-scale atmospheric flows, Atmos. Environ., 19, 2099-2108, 1985.

Iversen, T.: Numerical modelling of the long range atmospheric transport of sulphur dioxide and particulate sulphate to the Arctic, Atmos. Environ., 23, 2571-2595, 1989.

Kahl, J. D. W., Martinez, D. A., Kuhns, H., Davidson, C. I., Jaffrezo, J.-L., and Harris, J. M.: Air mass trajectories to Summit,
Greenland: A 44-year climatology and some episodic events, J. Geophys. Res., 102, 26861-26875, 1997.

Kasischke, E. S., Hyer, E. J., Novelli, P. C., Bruhwiler, L. P., French, N. H. F., Sukhinin, A. I., et al.: Influence of boreal fire emissions on Northern Hemisphere atmospheric carbon and carbon monoxide, Global Biogeochem. Cycles, 9, GB1012, doi:10.1029/2004GB002300, 2005.

Khokhar, M. F., Frankenberg, C., Van Roozendael, M., Beirle, S., Kühl, S., Richter, A., et al.: Satellite observations of atmospheric $\mathrm{SO} 2$ from volcanic eruptions during the time-period of 19962002, Adv. Space Res., 36, 879-887, 2005.

Klonecki, A., Hess, P., Emmons, L., Smith, L., Orlando, J., and Blake, D.: Seasonal changes in the transport of pollutants into the Arctic troposphere-model study, J. Geophys. Res., 108, 8367, doi:10.1029/2002JD002199, 2003.

Koch, D. and Hansen, J.: Distant origins of arctic black carbon: A Goddard Institute for Space Studies modelE experiment, J. Geophys. Res., 110, D04204, doi:10.1029/2004JD005296, 2005.

Krecl, P., Strom, J., and Johansson, C.: Carbon content of atmospheric aerosols in a residential area during the wood combustion season in Sweden, Atmos. Environ., 41, 6974-6985, 2007.

Lack, D., Lerner, B., Granier, C., Baynard, T., Lovejoy, E., Massoli, P., et al.: Light absorbing carbon emissions from commercial shipping, Geophys. Res. Lett., 35, L13815, doi:10.1029/2008GL033906, 2008.

Law, K. and Stohl, A.: Arctic air pollution: Origins and impacts, Science, 315, 1537-1540, 2007.

McConnell, J., Edwards, R., Kok, G., Flanner, M., Zender, C., Saltzman, E., et al.: 20th-century industrial black carbon emissions altered Arctic climate forcing, Science, 317, 1381-1384, 2007.

Mitchell, J. M.: Visual range in the polar regions with particular reference to the Alaskan Arctic, J. Atmos. Terr. Phys., 17, 195211, 1957.

Morin, S., Savarino, J., Frey, M., Yan, N., Bekki, S., Bottenheim, J., and Martins, J.: Tracing the origin and fate of NOx in the Arctic atmosphere using stable isotopes in nitrate, Science, 322, 730-732, 2008.

Nansen, F.: Blant sel og bjørn, H. Aschehoug \& CO, Oslo, 1961.

Nordenskiöld, A. E.: Nordenskild on the inland ice of Greenland, Science, 2, 732-739, 1883.

Oltmans, S. J., Lefohn, A. S., Harris, J. M., Galbally, I., Scheel, H. E., Bodeker, G., et al.: Long-term changes in tropospheric ozone, Atmos. Environ., 40, 3156-3176, 2006.

Paris, J.-D., Stohl, A., Nédélec, P., Arshinov, M. Yu., Panchenko, M. V., Shmargunov, V. P., Law, K. S., Belan, B. D., and Ciais, P.: Wildfire smoke in the Siberian Arctic in summer: source characterization and plume evolution from airborne measurements, Atmos. Chem. Phys., 9, 9315-9327, 2009, http://www.atmos-chem-phys.net/9/9315/2009/.

Polissar, A., Hopke, P., Paatero, P., Kaufmann, Y., Hall, D., Bodhaine, B., et al.: The aerosol at Barrow, Alaska: Long-term trends and source locations, Atmos. Environ., 33, 2441-2458, 1999.

Polissar, A., Hopke, P., and Harris, J.: Source regions for atmospheric aerosol measured at Barrow, Alaska, Environ. Sci. Technol., 35, 4214-4226, 2001.

Quinn, P., Shaw, G., Andrews, E., Dutton, E., Ruoho-Airola, T., and Gong, S.: Arctic haze: Current trends and knowledge gaps, 
Tellus series B-Chemical and Physical Meteorology, 59, 99-114, 2007.

Quinn, P. K., Bates, T. S., Baum, E., Doubleday, N., Fiore, A. M., Flanner, M., Fridlind, A., Garrett, T. J., Koch, D., Menon, S., Shindell, D., Stohl, A., and Warren, S. G.: Short-lived pollutants in the Arctic: their climate impact a nd possible mitigation strategies, Atmos. Chem. Phys., 8, 1723-1735, 2008, http://www.atmos-chem-phys.net/8/1723/2008/.

Raatz, W. and Shaw, G.: Long-range tropospheric transport of pollution aerosols into the alaskan arctic, J. Clim. Appl. Meteorol., 23, 1052-1064, 1984.

Radke, L. F. and Hobbs, P. V.: Arctic hazes in summer over Greenland and the North American Arctic. III: A contribution from natural burning of carbonaceous materials and pyrites, J. Atmos. Chem., 9, 161-167, 1989.

Rahn, K., Borys, R., and Shaw, G.: Asian source of Arctic haze bands, Nature, 268, 713-715, 1977.

Rahn, K.: Relative importances of North-America and Eurasia as sources of Arctic aerosol, Atmos. Environ., 15, 1447-1455, 1981.

Rahn, K. A. and McCaffrey, R. J.: On the origin and transport of the winter Arctic aerosol, University of Rhode Island, 486-503, 1980.

Rahn, K. A.: On the causes, characteristics and potential environmental effects of aerosol in the Arctic atmosphere, The Arctic Ocean, the Hydrographic Environment and Fate of Pollutants, 163-195, 1982.

Seibert, P., Kromp-Kolb, H., Baltensperger, U., Jost, D. T., Schwikowski, M., Kasper, A., and Puxham, H.: Trajectory analysis of aerosol measurements at high alpine sites, in: Transport and Transformation of Pollutants in the Troposphere, edited by: Borrell, P., Cvitaš, T., and Seiler, W., 689-693, Academic Publishing, Den Haag, 1994.

Seibert, P. and Frank, A.: Source-receptor matrix calculation with a Lagrangian particle dispersion model in backward mode, Atmos. Chem. Phys., 4, 51-63, 2004, http://www.atmos-chem-phys.net/4/51/2004/.

Sharma, S., Lavoue, D., Cachier, H., Barrie, L., and Gong, S.: Long-term trends of the black carbon concentrations in the Canadian Arctic, J. Geophys. Res., 109, D15203, doi:10.1029/2003JD004331, 2004.

Sharma, S., Andrews, E., Barrie, L., Ogren, J., and Lavoue, D.: Variations and sources of the equivalent black carbon in the high Arctic revealed by long-term observations at Alert and Barrow: 1989-2003, J. Geophys. Res., 111, D14208, doi:10.1029/2005JD006581, 2006.

Sharma, S., Ishizawa, M., Chan, D., Lavoué, D., Leaitch, R., Worthy, D., et al: Synoptic Transport of Anthropogenic BC to the Arctic, NOAA annual meeting, Boulder, Colorado, 2009.

Sheridan, P. J., Delene, D. J., and Ogren, J. A.: Four years of continuous surface aerosol measurements from the Department of Energy's Atmespheric Radiation Measurement Program Southern Great Plains Cloud and Radiation Testbed site, J. Geophys. Res., 106, 20735-20747, 2001.

Shindell, D.: Local and remote contributions to Arctic warming, Geophys. Res. Lett., 34, L14704, doi:10.1029/2007GL030221, 2007.

Shindell, D. T., Chin, M., Dentener, F., Doherty, R. M., Faluvegi, G., Fiore, A. M., et al.: A multi-model assessment of pollu- tion transport to the Arctic, Atmos. Chem. Phys., 8, 5353-5372, 2008 , http://www.atmos-chem-phys.net/8/5353/2008/.

Simpson, W. R., von Glasow, R., Riedel, K., Anderson, P., Ariya, P., Bottenheim, J., et al.: Halogens and their role in polar boundarylayer ozone depletion, Atmos. Chem. Phys., 7, 4375-4418, 2007, http://www.atmos-chem-phys.net/7/4375/2007/.

Sirois, A. and Barrie, L.: Arctic lower tropospheric aerosol trends and composition at alert, Canada: 1980-1995, J. Geophys. Res., 104, 11599-11618, 1999.

Solberg, S., Schmidbauer, N., Semb, A., Stordal, F., and Hov, Ø.: Boundary-layer ozone depletion as seen in the Norwegian Arctic in spring, J. Atmos. Chem., 23, 301-332, 1996.

Stohl, A.: Trajectory statistics - A new method to establish sourcereceptor relationships of air pollutants and its application to the transport of particulate sulfate in Europe, Atmos. Environ., 30, 579-587, 1996.

Stohl, A.: Computation, accuracy and applications of trajectories a review and bibliography, Atmos. Environ., 32, 947-966, 1998.

Stohl, A., Hittenberger, M., and Wotawa, G.: Validation of the lagrangian particle dispersion model FLEXPART against largescale tracer experiment data, Atmos. Environ., 32, 4245-4264, 1998.

Stohl, A., Eckhardt, S., Forster, C., James, P., Spichtinger, N., and Seibert P.: A replacement for single back trajectory calculations in the interpretation of atmospheric trace substance measurements, Atmos. Environ., 36, 4635-4648, 2002.

Stohl, A., Forster, C., Frank, A., Seibert, P., and Wotawa, G.: Technical note: The Lagrangian particle dispersion model FLEXPART version 6.2, Atmos. Chem. Phys., 5, 2461-2474, 2005, http://www.atmos-chem-phys.net/5/2461/2005/.

Stohl, A.: Characteristics of atmospheric transport into the arctic troposphere, J. Geophys. Res., 111, D11306, doi:10.1029/2005JD006888, 2006.

Stohl, A., Andrews, E., Burkhart, J., Forster, C., Herber, A., Hoch, S., et al.: Pan-arctic enhancements of light absorbing aerosol concentrations due to North American boreal forest fires during summer 2004, J. Geophys. Res., 111, D22214, doi:10.1029/2006JD007216, 2006.

Stohl, A., Berg, T., Burkhart, J. F., Fjae'raa, A. M., Forster, C., Herber, A., Hov, Ø., Lunder, C., McMillan, W. W., Oltmans, S., Shiobara, M., Simpson, D., Solberg, S., Stebel, K., Strm, J., Trseth, K., Treffeisen, R., Virkkunen, K., and Yttri, K. E.: Arctic smoke - record high air pollution levels in the European Arctic due to agricultural fires in Eastern Europe in spring 2006, Atmos. Chem. Phys., 7, 511-534, 2007,

http://www.atmos-chem-phys.net/7/511/2007/.

Uppala, S., Kallberg, P., Simmons, A., Andrae, U., Bechtold, V., et al.: The ERA-40 re-analysis, Q. J. Roy. Meteorol. Soc, 131, 2961-3012, 2005.

Vasconcelos, L., Kahl, J., Liu, D., Macias, E., and White, W.: A tracer calibration of back trajectory analysis at the Grand Canyon, J. Geophys. Res., 101, 19329-19335, 1996a.

Vasconcelos, L., Kahl, J., Liu, D., Macias, E., and White, W.: Spatial resolution of a transport inversion technique, J. Geophys. Res.-Atmos., 101, 19337-19342, 1996b.

Warneke, C., Bahreini, R., Brioude, J., Brock, C. A., de Gouw, J. A., Fahey, D. W., et al.: Biomass burning in Siberia and Kazakhstan as an important source for haze over 
Alaskan Arctic in April 2008, Geophys. Res. Lett., 36, L02813, doi:10.1029/2008GL036194, 2009.

Warren, S. and Wiscombe, W.: Dirty snow after nuclear-war, Nature, 313, 467-470, 1985.

Watanabe, K., Nojiri, Y., and Kariya, S.: Measurements of ozone concentrations on a commercial vessel in the marine boundary layer over the northern North Pacific Ocean, J. Geophys. Res., 110, D11310, doi:10.1029/2004JD005514, 2005.

Weingartner, E., Saathoff, H., Schnaiter, M., Streit, N., Bitnar, B., and Baltensperger, U.: Absorption of light by soot particles: Determination of the absorption coefficient by means of aethalometers, J. Aerosol Sci., 34, 1445-1463, 2003.
White, P. W.: ECMWF, IFS Documentation, ECMWF, Reading, 2002.

Worthy, D. E. J., Trivett, N. B. A., Hopper, J. F., and Bottenheim, J. W.: Analysis of long-range transport events at Alert, Northwest Territories, during the Polar Sunrise Experiment, J. Geophys. Res., 99, 25329-25344, 1994.

Worthy, D. E., Platt, J. A., Kessler, R., Ernst, M., and Racki, S.: The greenhouse gases measurement program, measurement procedures and data quality, in: Canadian baseline program; summery of progress to 2002, edited by: Canada, M. S. O., 97-120, 2003.

Wotawa, G. and Trainer, M.: The influence of Canadian Forest Fires on Pollutant Concentrations in the United States, Science, 288, 1367-1377, 2000. 